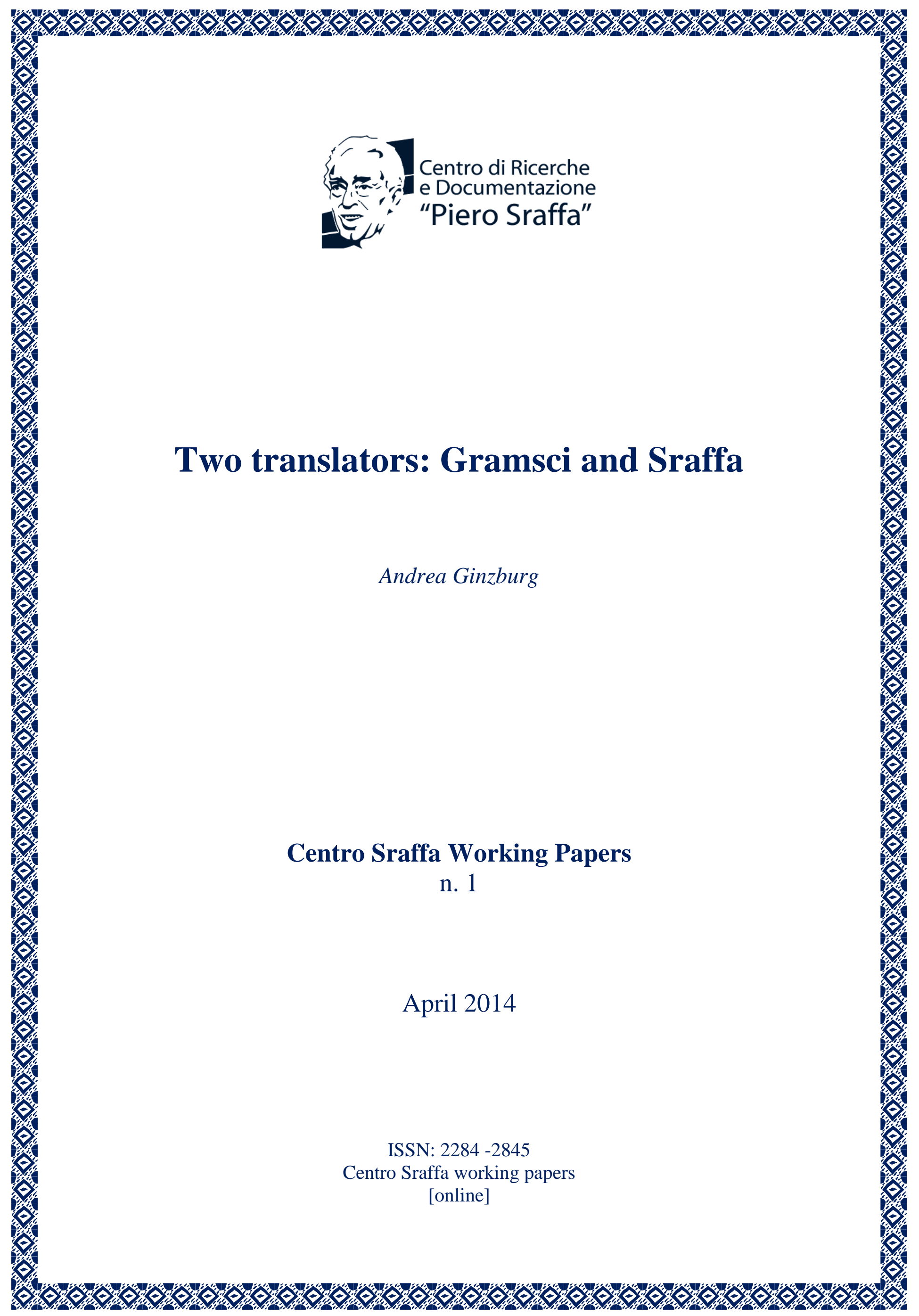




\title{
Two translators: Gramsci and Sraffa
}

\author{
Andrea Ginzburg \\ Università degli Studi di Modena e Reggio Emilia
}

\begin{abstract}
Through the Prison Notebooks and the papers left by Sraffa, it is possible to attempt a reconstruction of the intellectual paths taken by the two authors and discover unexpected convergences, as well as obvious differences. The key concept employed here is that of the 'translatability of scientific languages'. From this concept, Boothman has argued, stems the 'open' character of Gramsci's Marxism. The theme of the translatability of languages is also present in Sraffa: in a Note written after the important theoretical turning point of the summer of 1927, he states his intention to write a book that will consist in the translation of Marx into English, that is in the translation of the 'metaphysics' of Hegel into that of Hume. It can be shown that issues that have a prominent importance in Gramsci's thought help us to understand the meaning and importance of Production of Commodities by Means of Commodities.
\end{abstract}

Keywords: Sraffa, Gramsci, Ricardo, Surplus Approach, causality

JEL Codes: B00, B24, B51

\section{Introduction ${ }^{1}$}

Much has been written on the relations between Antonio Gramsci and Piero Sraffa but, as has been noted ${ }^{2}$, there are still many topics to clarify and examine in depth. With

\footnotetext{
${ }^{1}$ I wish to thank Nerio Naldi who, as on other occasions, was generous in providing me with information and documents. I am also grateful to Giovanni Bonifati, Antonia Campus, Antonio Di Meo, Carlo Ginzburg, Tim Keates, Nerio Naldi, Antonella Palumbo, Anna Simonazzi and Paolo Trabucchi for their comments on an earlier version of this paper (exempting them, of course, from any responsibility). Here and there I have used two previous writings of my own Ginzburg (2000) and Ginzburg (2013), to which I refer the interested reader for further details. A somewhat shorter Italian version of the paper was published in Il Cannocchiale, rivista di studi filosofici, 3, 2012, in a special number dedicated to Gramsci, edited by Antonio Di Meo.

${ }^{2}$ See Auletta (2008), p. 485.
} 
regard to political positions, for example, it still remains to be determined ${ }^{3}$ where to place the path taken by Sraffa after 1924 in relation to that followed by Gramsci, by the Italian Communist Party, by the British Communist Party (since Sraffa resided in England after 1927) and by the Communist International. In terms of theoretical research — the sole aspect to be dealt with in this paper — the information that can be drawn from the letters exchanged with Tania during Gramsci's imprisonment is too sparse, especially when read out of context, to furnish an exhaustive picture of their mutual influences. Nor has clarification been assisted by simplistic ${ }^{4}$ interpretations of the personality of both, but especially of Sraffa, seen from time to time through a single dimension and often reductive, merely as a friend or as a passive intermediary of Togliatti or others and never as an interlocutor and autonomous subject .

Here I will briefly recall a number of circumstances that converge to minimize the importance of an analysis based exclusively on direct communications or written evidence. First, of course, the prison mail censorship after Gramsci's arrest that took place in 1926. Then that Sraffa himself who, when asked by Spriano in 1967 if he was willing to give evidence or access to documents on meetings with Gramsci, replied that he was available to answer questions as far as his memory permitted, but "after thirty years of silence" he was not willing to give a real "testimony". He added: "I have no notes as between the Scylla and Charybdis of the two police forces, fascist and British, I've never taken any." It should be emphasized that Sraffa's silence (or reticence) concerned not only Gramsci's political relationships with the Communist party, but also his own relations with Gramsci, Wittgenstein ${ }^{6}$ and others. Sraffa's complex personality does not provide easy explanations for these silences, but, as I have written elsewhere ${ }^{7}$, I believe that such explanations should be sought, in the first approximation, in the confluence of three characteristics of that personality: first, his "perfectionism" - that is, his fear of incorrectness or imprecision; second, his fear of being misunderstood; and lastly a keen sense of political opportuneness, given the hostility of the environment even in a democratic regime. This sense of political opportuneness concerned not the ideas themselves but the way they are presented, or the choice to remain silent. One may conjecture that these characteristics were merged in the concern that a false step could jeopardize the "cause". It is reported by several witnesses that for Sraffa, as also for Gramsci $^{8}$, criticisms or reservations levelled, from the "inside", at the Bolshevik

\footnotetext{
${ }^{3}$ See Naldi (2008), p. 527.

${ }^{4}$ I refer in particular to Rossi and Vacca (2007). But see also Vacca (2012).

5 See Spriano (1967), pp.14 -16. On the corrections requested by Sraffa after the first draft of the interview carried out by Spriano, see Vacca (2000), p. 60-65.

${ }^{6}$ See, for example Potier (2000), p.31 .

7 See Ginzburg (2000), pp. 139-40 .

8 Even Vacca (2012), p.313, notes, albeit in passing, that, despite his dissent from Stalin's policy, Gramsci "never put into question his loyalty to the land of the Soviets, nor ever thought of separating from the communist movement".
} 
policy never led to separation from the Communist movement or to abandoning the idea (as Valiani stated in an obituary of Sraffa) that "the future will be forged in the USSR."9

The possibility of relying solely on the limited exchanges between them in writing in order to reconstruct their intellectual relations is further hampered by the intensity of their conversations occurring mainly between spring 1924 and autumn $1926^{10}$. Sergio Steve $^{11}$ testifies that Sraffa described his conversations with Gramsci in the following words: "The intensity and vividness were such that we could begin to discuss at dinner, and continue throughout the night and the next day, without ever being tired." Presumably, the time limits and the strict surveillance under which they talked during Gramsci's imprisonment were at least partly mitigated by their sharing common interests as well as some important readings and the crucial ability, common to both, to reconstruct the whole starting from a few, isolated elements (see Cuvier's little bone mentioned by Gramsci in Q.1, §3, p. 22 and Q. 28, §3, p. $2327^{12}$ ). Lastly, the study of their mutual influences and the chronology of these is complicated by the fact that certain analyses presented in youthful publications ${ }^{13}$ very clearly anticipated reflections that would not be developed until much later.

In this paper I propose to show that some crucial issues of Gramsci's research occupy a prominent place also in Sraffa's theoretical approach and in the results obtained by him. The comparison, at this stage, is a predominantly morphological one, so - for the reasons outlined above - I will not be concerned with chronology or causality issues to ascertain the directionality of the influence of one on the other, and the circumstances in which such influence may have been exerted. ${ }^{14}$ These issues will be addressed later, if the morphological comparison proposed here is found to be convincing. Moreover, at this stage, an extensive search in a non-morphological direction is hampered by an obvious asymmetry. In what follows I shall draw on the significant results (including philological ones) obtained by research on Gramsci, especially on the Prison Notebooks, over the past decade; but study of numerous

\footnotetext{
${ }^{9}$ See Valiani (1983). See also Giolitti (1992), p.80. One aspect not considered here, namely the issue of the regulation of the economy, could perhaps provide some indication on how Gramsci and Sraffa, in different ways, tried to reconcile anti-determinism in the social domain and 'Sovietism'.

${ }^{10}$ See Naldi (2008 ) p. 519, note 30. As is known, other meetings between Sraffa and Gramsci took place between 1935 and 1937 when Gramsci was under police surveillance in a private clinic.

${ }^{11}$ See Steve (2004), p. 17. On the years 1919-1927 see Naldi (1998) and Naldi (2000). For evidence on the "intense intellectual elaboration" dedicated by Gramsci to readings and proposals during his stay in Vienna before the return to Rome in 1924, and on the books brought back to Italy, including an anthology containing excerpts from The German Ideology and the Introduction to A Contribution to the Critique of Political Economy of 1857, see Izzo (2009), pp.45-46 and 52.

${ }^{12}$ Engl. transl., vol. I, p. 116. The Buttigieg translation covers at the moment the Notebooks 1-8. Henceforth the letter Q followed by a number refers to the number of the Prison Notebook, see the Gerratana Italian edition, Gramsci (1975).

${ }^{13}$ See, for example, 'Utopia' of July 1918 on structure and superstructure, in Gramsci (1984), pp. 204 212, to which Cospito (2011), pp. 70-1, has drawn attention.

${ }^{14}$ The two major works of Sraffa published after 1926, the introduction to The Works and Correspondence of Ricardo (1951) and Production of Commodities by Means of Commodities (1960), are subsequent to the publication of Gramsci's Notebooks, but the basic lines of his research had been outlined between 1927 and 1931 .
} 
unpublished papers left by Sraffa is still in its infancy as regards the topics dealt with in this paper since it appears fragmentary and has recorded many false starts. Undoubtedly, "the tendency to 'strain' the texts," as Frosini and Liguori write, has characterized much of the interpretation [of Gramsci] and has perhaps become even stronger over the last decade." 15 They attribute this trend to the 'open' and necessarily cryptic character of his Notebooks and to the mingling of theory and politics that "inevitably" accompanied the reading and interpretation of texts. This resulted in "stretching, partiality, one-sidedness", the same risks to which interpreters of Sraffa (including, of course, the present writer) are prone, for similar reasons. But in this way the readers of Gramsci's texts may have some orientation ${ }^{16}$ on the terms of the current debate - whereas this is totally lacking in the case of Sraffa's writings, published and unpublished.

I will try to show the existence, in Sraffa's unpublished works and his overall theoretical framework that emerges in his 1960 book, Production of Commodities by Means of Commodities, of a correspondence (which does not exclude differences ) with important terms of the vocabulary of Gramsci, such as 'translation and translatability', 'structure and superstructure', 'historical materialism', 'determinism and mechanicism', 'dialectics', 'strength relations', 'metaphor and myth'. In other words, I propose an exercise in 'translation, ${ }^{17}$ : according to the meaning attributed by Gramsci ${ }^{18}$, 'translate' is close to the concept of "transpose, find matches or differences between the "idioms'."

Since both in the texts of Gramsci and in those of Sraffa we often find the implicit reference to texts and interpretations of Marx, it is necessary to start with a brief exposition, in broad terms and without any claim to completeness, of the change in the position taken by Sraffa, as well as Gramsci, in the course of time, with respect to some important aspects of Marx.

\section{2 . The many 'Marxes' of Gramsci, the many 'Marxes' of Sraffa}

2.1 The title of this section alludes to an essay ${ }^{19}$ by Francesca Izzo entitled "I Marx di Gramsci" that can be translated as "The many Marxes of Gramsci". Reference to the writings of Marx is a constant in Gramsci's reflection, but the author points out a significant difference in the use of Marxian thought among the early writings (at least until 1922), and Prison Notebooks. In the first phase, Marx is just one of the reference points used by Gramsci in the cultural and political battles waged against determinism and positivism within the Socialist Party and in the controversy with Bordiga. His

\footnotetext{
${ }^{15}$ See Frosini and Liguori (2004), p. 9.

${ }^{16}$ See the useful reconstruction of the discussions arising around the texts of Gramsci proposed by Guido Liguori in the two editions (1996 and 2012) of the book Gramsci conteso ('Gramsci contended') .

${ }^{17}$ Or rather, as we shall see, of 'meta-translation'.

${ }^{18}$ See Boothman (2004a), p. 247, quoting Marzani (1957), the first English translator of a selection of the Notebooks.

${ }^{19}$ See Izzo (2009), p. 23-74. For an acute and in-depth analysis of how Gramsci's reflection developed starting from 1924, therefore with an earlier chronology with respect to Izzo's reconstruction, cf. Paggi (1974), now in Paggi (1984), pp. 427-498 .
} 
polemic fits in the more general idealistic reaction against the 'philosophy of history' of positivism, defined by Garin as a claim to "a definitive overcoming of 'metaphysics' by the positive sciences...the illusion of absorption of each dimension of human progress by the development of science and technology." ${ }^{20}$ Even in Marx Gramsci tends to find elements similar to positivism: therefore "he is induced by his training" to read him "through the grid of the philosophies of action and life, from Bergson to Sorel, and especially to filter him with the categories of neo-idealism".

Instead, in the Notebooks, as Francesca Izzo writes, Gramsci makes a 'rediscovery' of Marx, finally freed from the interpretations of Gentile ${ }^{21}$ and Croce. After the victory of fascism, the failure of revolution in Europe and the retreat of Soviet policy to a territorial basis, he feels acutely the lack of a theoretical autonomy in the labour movement ${ }^{22}$. Hence the need for a reflection on the theory of historical materialism in the search for solid foundations in it "for an autonomous vision of man, of history, of politics." ${ }^{23}$ The development of Gramsci's concepts such as 'philosophy of praxis', 'translatability of languages', 'hegemony', 'passive revolution' and so on, starts out from the writings of Marx (in particular the 1859 preface to the Contribution to the Critique of Political Economy, the Holy Family, the Poverty of Philosophy and the Theses on Feuerbach, and the historical writings), in the light of relevant texts of Lenin and Labriola.

It is not necessary to deal with these issues here except to recall that, for Gramsci, the loss of autonomy in the theory of Marxism - an essential premiss for political autonomy - comes from having lost sight of the "unity of the conception of the world", the "dialectical unity" between matter and spirit, and between economics, politics and philosophy. This unity has been dissolved into its components, thus creating the conditions of cultural subordination. This fragmentation is to be overcome through "the conceptualization of a total immanence which involves the criticism of every presupposition, material or spiritual, that is presumed to transcend historicity, i.e. the conflicts, divisions and contradictions that mark the historical existence of humankind."24 Against 'monism', whether materialist or spiritual, Gramsci opposed

\footnotetext{
${ }^{20}$ See Garin (1983), p. 329 quoted in Izzo (2009), p. 29.

21 On Gramsci's Italian translations of Theses on Feuerbach to distance himself from Gentile's interpretation, cf. Frosini (2004 ), p. 99.

${ }^{22}$ See the letter to Tania of March 25, 1929 in Gramsci and Schucht (1997), p. 331; Izzo (2009), p. 52, emphasizes the continuity of Gramsci's reflection between the period before the arrest and the research program of the Notebooks, but it is interesting to note that Frosini (2003), p. 45-46, detects instead the existence of a discontinuity in Gramsci's research program between 1927 and 1929, a period in which "Gramsci feels the need to open a space for reflection on the theory of historical materialism". In the context of the polemic against Bordiga's maximalism, considered a mix of intransigence, determinism and fatalism, in 1926 Gramsci (1978), p.102, wrote: "It was characteristic... of the false position of the extreme left that his observations and his criticisms were never based either on a in-depth nor even on a superficial examination of strength relationships and of the general conditions existing in Italian society. It thus became clear that the proper method of the extreme left, that by the extreme left itself is called dialectical, is not Marx's method of dialectical materialism, but the old method of conceptual dialectics of pre-Marxist and even pre-Hegelian philosophy".

${ }^{23}$ See Izzo (2009), p. 53 and Q.. 17, §12, p. 1917.

${ }^{24}$ See Izzo (2009), p. 59.
} 
historical materialism, "human activity (history) in practice, i.e. applied to a certain organized 'matter' (material forces of production), transformed by man" ${ }^{, 25}$.

From here stems the polemic conducted by Gramsci on two fronts: anti-idealistic (against Benedetto Croce), and against the deterministic and mechanistic positions engendered by the reduction of Marxism to 'ultra-materialism' (against Bukharin 's Theory of Historical Materialism. A Manual of Marxist Sociology and, by extension, against the positions predominating in Soviet policy at that time $)^{26}$. Whereas in 1925 Gramsci had actually announced plans to use Bukharin's book as lecture notes in a course for the school within the party ${ }^{27}$, in the Notebooks he accuses him of providing a "superficial approach to the problem of historical materialism" because "to explain history" Bukharin has taken "the causal element from the natural sciences." This meant coming back to "the old ideological historiography (idealistic or materialistic)": in this way it was impossible to endow the concept of historical materialism with "its own scientific autonomy and its proper status vis-à-vis the natural sciences-or, [more importantly] vis-à-vis that vague concept of 'science' in general that is typical of vulgar popular thought". ${ }^{28}$

2.2 In a letter to Sraffa from the 'confino' (internal exile) in Ustica dated December $11,1926^{29}$, Gramsci asks his friend to send him "a good treatise on economics and finance to study: a fundamental book." In December, he received the Italian translation (published in 1925) of Marshall's Principles. At the time Sraffa, though with some doubts or reservations that emerge in a few of the notes to his articles in 1925 and 1926, agreed with Marshall's interpretation of the classical economists. Only a constant supply curve, he argued in 1926, is compatible with the assumption of coeteris paribus which in competition characterizes partial equilibrium. It followed that the demand curve would have no influence on the equilibrium price. Hence his conclusion: "And so, as a simple way of approaching the problem of competitive value, the old and now obsolete theory which makes it dependent on the cost of production alone appears to hold the ground as the best available" ${ }^{30}$.

In a manuscript of about seventy pages entitled 'Notes/London Summer 1927/Physical real costs, etc.' prepared for a course of lectures at Cambridge which would then be postponed by a year to October of 1928, Sraffa, in the space of a few

\footnotetext{
${ }^{25}$ See Gramsci, Q. 4, §37, p. 455 (engl. transl. slightly different, vol. II, p. 177).

${ }^{26}$ Bukharin's book was defined by V. Mikecin "an aspect of the genesis of Stalinism”. See Gerratana's introduction to Bukharin (1977), p. XIV, note 20. See also Ginzburg (2000), p. 135.

${ }^{27}$ See Gramsci (1978), p. 56. In the Italian translation of the lecture notes, Gramsci introduced a significant interpolation in the final part of Bukharin's introduction, which can be interpreted as a way of taking a distance from purely doctrinal interpretations of historical materialism. See Paggi (1984), p.449450.

${ }^{28}$ See Q.4, § 25, p.444, engl. transl. Vol. II, p.165. For an analysis of Gramsci’s reflections on science, cf. Di Meo (2008).

${ }^{29}$ See Gramsci (1965), p. 13. Gramsci's stay in Ustica lasted 44 days. After Gramsci's arrest and incarceration in Milan, the book was held in Ustica by Gramsci's fellow exiles (cf. Gramsci 1997, p. $105)$.

${ }^{30}$ Cf. Sraffa (1926), p. 540-1.
} 
months, developed a point of view that distanced him sharply from Marshall's interpretation, and led him to rediscover the approach of the classical economists and see Marx's theory of value in a completely different light. This turnaround, both theoretical and interpretative, occurred in a few months between the summer and November of 1927, though not until later was it made more specific and explored in depth. This is not the point to retrace all the steps and the results of the discovery; the reader is referred to the detailed analysis by Garegnani ${ }^{31}$. I will focus here only on some points of Garegnani's reconstruction that seem relevant to a 'morphological' comparison with the interpretations of Marx provided by Gramsci.

At the beginning of the manuscript, which Garegnani calls 'pre-lectures', Sraffa considers the determination of prices by the apparatus of supply and demand to be an idea of "immense scientific importance". It should be noted that the assumption of constancy of the supply curve — Garegnani recalls ${ }^{32}$ — led (albeit in the Marshall's hypothesis of partial equilibrium) to expunging "the subjective elements of 'utility' and "disutility" from that apparatus even while the determination of relative prices through the Marshallian supply and demand functions was attributed to the classical economists. The specific reasons for this "immense importance" can be ascribed, according to the author of the "pre-lectures" 33 , to the merit of having "wiped out the primitive notion that there had to be somewhere or other one single, ultimate cause of value." This "primitive notion", attributed to Ricardo and the other classical economists, would underlie a "philosophical as opposed to a technical outlook" and its relinquishment would thus be in line with "the general scheme of progress in science". In particular, the concept of equilibrium would therefore fulfill its mission to 'purge' economic analysis of philosophical elements in two different ways. First, "it has had the great practical advantage that, being to a certain extent compatible with both [schools of thought ${ }^{34}$ (since it embodied their doctrines)", it has put an end to "the old controversy and brought back the T.[heory of] V[alue], from the field of politics to that of economic theory." Second, the notion of equilibrium "put as [the] principal problem to be solved by the T.[heory of] V[alue], not the question of the causes of the value of all commodities together, but the determinants of the value of one article considered separately, and regarded as independent from all the others." In conclusion, the equilibrium between supply and demand proposed by Marshall would result, according to Sraffa, in the return from philosophy to science, because it was concerned with focusing the attention on "the mechanism through which the actual price of such things as boots or candles was fixed" and not, as the classical economists have it, on the "cause

\footnotetext{
${ }^{31}$ See Garegnani (2004) and (2005). For a different interpretation of the path followed by Sraffa to reach the theoretical turning point of 1927, cf. De Vivo (2003) and Gilibert (2003) .

${ }^{32}$ See Garegnani (2004), p. 162 .

${ }^{33}$ See Sraffa Papers D3/12/3.

${ }^{34}$ These are the two schools of the 'cost' (Ricardo) and 'utility' (associated with Jevons, Menger and Walras). The latter, Sraffa notes, originated as a reaction when Marx "had taken up Ricardo's theory 'cost' and brandished it as a weapon in favour of the workers".
} 
of value" or "on estimating the wealth of a nation" (Smith), or at a later stage (Ricardo), on "what we call 'distribution'."

At this point Sraffa would encounter some analytical problems leading him to reassess the importance of the search for the "cause of value" — in a non-metaphysical sense - conducted by the classical economists. First, the problem of the "cause of value" is closely related to the theory of distribution between wages and profits. It should be remembered that it was through the labour theory of value that Ricardo had based his conclusion on the existence of an inverse relationship between wages and the rate of profits by hypotheses more general than those considered in the previous Essay on Profits.

In the classical economists, Sraffa notes, there is a "separate theory of distribution" to which "we do give ... a very great importance" but, in addition, there is a different and also very important question - the fixing of prices of single articles. "Besides he adds - it has been found that the two questions cannot be treated simultaneously: different general assumptions and different methods of analysis are required" Secondly, when you wish to consider the problem of determining the prices of all the goods and not merely of a single commodity in isolation from all others, in order to avoid the circular reasoning of using prices to determine prices, "we have to find some ultimate standard, independent from the variables we are considering, such [as] utility or disutility or labour". Thirdly, if we want to overcome the limitations of the assumptions of partial equilibrium without sacrificing the explanatory power of the theory $^{36}$, the standard must be, at least in principle, observable. From this point of view 'utility' and 'labour' are definitely not on the same level. (At first, however, with respect to 'utility' and 'costs' as sacrifices or disutility, Sraffa had noted: "Two

\footnotetext{
${ }^{35}$ Emphasis added. Sraffa is here discussing the peculiar separation of production and price determination in the special hypothesis of Marshallian partial equilibrium. When considering the price determination of a single commodity, distribution and all other prices can be taken as given with respect to the output variation of that single commodity. Supply is considered horizontal, and demand does not influence the price of that article. Instead, in the more general case, prices and distribution are going to be mutually related and this would rise the problem of finding "an ultimate standard" to avoid the risk of circular reasoning. While still maintaining that "the ultimate forces which regulate the division of product of industry between factors are the same that regulate the price of hats" (i.e. supply and demand, italics added), Sraffa here observes: "this splitting up of questions, this power of abstraction and isolation is a feature of every scientific progress". On the concept of taking a "slice of the real world" declaring it to be an 'isolated system' see Whitehead (1925) quoted in Maurice Dobb's (1937) chapter on 'Requirements of a Theory of Value', p. 7. An analogous importance attributed to "the splitting up of questions" and to the "power of abstraction and isolation" is implicit in the separation of production and prices determination obtained, on different grounds, in the 'equations' of the 1960 book. In this case, the determination of variables inside or outside the 'core' requires "different general assumptions and different methods of analysis": the theory of prices must be studied at a higher level of abstraction (of generality) than that chosen by theory that deals with the determination of wages and quantities produced, which will be influenced by particular historical circumstances. I am indebted to Antonia Campus for an helpful discussion on this point.

${ }^{36}$ Sraffa maintains the idea, set out in 1926, according to which (see Sraffa, 1926, p. 541) the marginalist conception of general economic equilibrium seems too complex to be fruitful, "at least in the present state of our knowledge, which does not permit of even much simpler schemata being applied to the study of real conditions".
} 
standards are proposed: they are the same thing — words" ${ }^{, 37}$ ). The Marshallian symmetry between demand and supply is deteriorating in two points, the removal of the partial equilibrium assumption (i.e. the coeteris paribus hypothesis), and the criticism of the theoretical foundation of the demand function ${ }^{38}$.

The next step is the removal of the supply function. This is done by starting not from a reflection on 'labour' considered as such as a standard of value, but from the notion of 'physical real cost', i.e. the means of subsistence necessary to support the labour directly and indirectly used to produce the goods. I am not interested here in following the next steps that led Sraffa, in a non-linear way, to formulate the theory that would ultimately find a complete formulation in his 1960 book. What matters here is to emphasize the dual nature of the turning point - in both the theory and the history of economic thought, but it is difficult to distinguish the two aspects — which emerges from the notes written in the period Summer-November 1927, and that was to undergo a further important clarification, as I will say, in a note written in August 1931.

From the theoretical point of view, Sraffa's 'equations' allow the determination of the relative prices of goods and the uniform rate of profit starting only from the physical quantities of goods used in the production both as a means of production and as a means of subsistence. This separation between production on the one hand and prices on the other enables prices to be set without making any use of the supply and demand apparatus. "In short - Sraffa writes - the equations show that the conditions of exchange are entirely determined by the conditions of production." 39 Moreover, it should be stressed that, unlike in the marginalist theory, no change is here assumed: the analysis refers to a given situation (a 'snapshot', albeit sui generis ${ }^{40}$ ), wherein the amounts of the individual goods (together with the production techniques and real

\footnotetext{
${ }^{37}$ In a general equilibrium context, Sraffa writes, "is not enough to make the utility of one commodity function of quantity of all others consumed by individual, but also by community! It would be as if in astronomy we said the movement of each star depends upon all others, but we have not the faintest idea of the shape of the functions!" (A4, 21. x.x1, quoted in Garegnani (2005), p.464. It may be noted here that Sraffa points out the gap between the procedure normally acceptable in a community of natural scientists (in this example, astronomers) and that utilized as a foundation for a utility-based theory of demand.

${ }^{38}$ In 1926, however, Sraffa wrote: "a functional connection between cost and quantity produced ... appears to have been present in the minds of the classical economists much less prominently than was the connection between demand and demand price." See Sraffa (1926), p.537.

${ }^{39}$ Sraffa papers, D3/12/7 .

${ }^{40}$ It is a snapshot only in the sense that the phenomena considered refer to a single period of production. The observation of social processes that develop over time is condensed into an instant in order to highlight their internal relations. In fact, it is a theoretical abstraction based on observation. The hypothesis of the uniformity of the rate of profit alludes to a process, a tendency, not directly observable in a given instant. Also the quantities produced that are among the data of the economic system do not correspond to current productions but are 'normal' production levels associated with the quantities demanded, in the long run, on the market. The term 'snapshot' is used by Sraffa himself in Sraffa Papers D3/12/13, Summer and October 1929. It can be observed that Gramsci, in listing the precautions employed by Marx in his historical works with respect to the assertions present in his theoretical works, speaks inter alia of "The difficulty of identifying the structure at any moment, statically (like an instantaneous photographic image" (Q.7, § 24,p. 872, February 1931, engl. transl. vol. III, p.174) .
} 
wages) are among the data of the problem (a point in the price/quantity space), and not considered as unknowns as in the marginalist theory ${ }^{41}$.

With regard to the implications of this perspective for the history of economic thought, I will recall here three points. The first concerns the rediscovery of the concept of surplus, the fraction of the product that remains after subtracting the production materials and the livelihood of the workers. This notion, first proposed by the physiocrats, was thereafter accepted, in various forms, sometimes in ambiguous or confused ways, by the proponents of the classical school and by Marx and it is, so to speak, the 'distinguishing mark' of the entire classical political economy.

The second aspect concerns the judgment to be given on Marx. Upon completing his reconstruction, Garegnani (2005, p. 485) concludes that "before the theoretical turningpoint", Sraffa undoubtedly had "a good knowledge of Marx. He sympathized with his political and philosophical theses and also with some aspects of his ideas on economic theory, but entertained doubts about the strictly economic rather than politicalphilosophical value of other aspects, including the labour theory of value". After the turnaround, Sraffa came to admire Marx's contribution in the economic field and planned a thorough study of his works. For two reasons. First, because Marx was able to resume the historical thread of a theoretical perspective based on the notion of surplus at a time when, even before marginalism, it had been lost. Second, for having dealt, through the labour theory of value, with an important analytical problem anything but metaphysical, namely how to express the aggregate of goods that make up the social surplus in labour in terms independent of prices and income distribution, thus avoiding the logical flaw of circular reasoning.

A third aspect concerns the bifurcation point between the two alternative theories of value and distribution: the classical one, underpinned by the idea of physical real costs of production based on wage conceived as an aggregate of means of subsistence; and the marginalist one, based on the wage as an inducement to the 'sacrifice' of work. This distinction enables us to highlight how in Marshall's theory the subjective element appears not only on the demand side (utility originating from consumption), but also on the supply side (in terms of 'subjective cost', the goods to which the sacrifice of work would allow access).

This brief review of the positions taken by Gramsci and Sraffa vis-à-vis certain important aspects of Marx's thought points to some convergences and a (possible) major divergence. Working along different paths, our authors agree on the need for a closer study of Marx's texts, purged of subsequent encrustations and conceptual ambiguities that have formed around them; they also share a commitment to an anti-idealist and anti-metaphysical stance (I will return on this point below). In addition, the extant writings of Sraffa provide a strictly analytical (not merely philosophical and moral) interpretation of the labour theory of value, understood as a theory of exchange relationships; nor does any philosophical or moral dimension of the labour theory of

\footnotetext{
${ }^{41}$ On this point and on the concept of 'core ', which emerges explicitly in August 1931, I will return later.
} 
value appear to be present in the writings of Gramsci. The (possible) difference concerns the apparent absence in Sraffa, in the summer of 1927, of a critical position opposed to the deterministic and mechanistic materialism (directed by Gramsci, for example, against Bukharin, as from $1930^{42}$ ), and indeed Sraffa's project, formulated at the beginning of the pre-lectures, to return "from politics to economic theory" in accordance with "the general scheme of progress in science." How does the theoretical turnaround of 1927 modify this project? Notwithstanding the project was already anticipated in that year, the existing documentation suggests that final clarification on this important point had to wait until 1931.

\section{Translation/translatability in Gramsci and Sraffa}

3.1 On the issue of translation and translatability in Gramsci much has been written in recent years. The abundant literature on this subject, to which I refer the reader, converges, seems to me to agree in considering it as an important starting point for understanding the process of the critical (and self-critical) reflection developed by Gramsci in the Notebooks. This path leads him at a certain point to replace the term 'materialism' and also 'historical materialism' with the term 'philosophy of praxis' and this not only for reasons of prison censorship. Starting from texts by Marx and Engels and Lenin, Gramsci expands the concept of translation extending it in a plurality of directions. From this expansion, according to Boothman ${ }^{43}$, comes the "open nature of the Gramscian Marxism ... [which] .. makes it different from any conception of Marxism as a closed system and specifically from that system that came to be called in the USSR (and elsewhere) 'Marxism-Leninism'."

The several meanings of the term ${ }^{44}$ include firstly 'translation' as trans-cultural and trans-political 'transfer/adaptation'. In fact Lenin in 1922, quoted by Gramsci, spoke of the difficulty of "presentation" of the experience of the Soviet revolution to Europeans in terms accessible to them. But the concept of 'translation' (in this case, of the revolution), as opposed to a simple 'presentation', is tantamount to denying the possibility of a mechanical transfer from one context to another. Moreover, the etymology of the term 'translation' in Italian has the same origin as 'tradition' and 'traitor' and thus expresses the coexistence of continuity and change. Secondly, there is the notion of 'translation' as correspondence/convertibility between different areas, that is, the translatability of scientific languages. In the Holy Family, Marx and Engels argued that the German speculative philosophy expressed "in German, that is, in

\footnotetext{
${ }^{42}$ See Q.1, $§ 153$ (engl. transl. vol. I, p.233), Q.4 §12, May-August 1930 (engl. transl. vol.II, p. 153) and Cospito (2011), p. 28-31. I do not share Cospito's interpretation (ibid., p.29) that the question advanced by Gramsci as to whether libraries should be considered structure or superstructure would be an indication of a bewilderment or, even worse, of a return to economism. This interpretation is based, it seems to me, on the erroneous identification, frequent among recent interpreters of Gramsci, between economics and economism .

${ }^{43}$ See Boothman (2004), p. 265.

${ }^{44}$ See Ives (2004), p. 99 et seq. and the references cited on p. 205.
} 
abstract thought," what French politics, through the concept of equality, expressed "in the language of politics and intuitive thinking." Translatability, in this case, assumes Gramsci writes - that "a given stage of civilization... [has] ... a basically equal cultural expression, even if the language is historically different, determined by the particular tradition of each national culture and of every philosophical system, and by the predominance of an intellectual activity or practice, etc..."

In a third meaning, translation is the instrument of the reconstruction of the conception of the world, dictated by the unit of theory and practice. In a note entitled "Philosophy-Politics-Economy", Gramsci writes "If we are dealing with the constituent elements of the same conception of the world, there must necessarily be, in the theoretical principles, convertibility from one to another, mutual translation of each constituent part in its own specific language: one element is implicit in the other and all of them together form a homogeneous circle." 46 This meaning of the word 'translation' is the most radical since, as Frosini writes ${ }^{47}$, there follows from "the relativisation of different languages... and the translation of philosophy into politics" (and into economic analysis, I might add). This meaning underpins the equation, postulated by Gramsci, Marx $=$ Hegel + Ricardo. And Gramsci's request in 1931 for advice and clarification on Ricardo from Sraffa starts out from that.

3.2 The issue of translation/translatability appears in Sraffa's unpublished papers at a crucial moment in his theoretical reflection. As can be seen from some earlier observations $^{48}$, in the fall of 1927 Sraffa, on the basis of insights gained as from the previous August, was planning a book that would show "the differences and the superiority of the old classical theories" with respect to contemporary theory. His aim - he wrote - was twofold: "I. Exposition of the history, which is truly the essential. II. Make myself understood: which requires me to proceed from the known to the unknown, from Marshall to Marx, from disutility to material cost." In a remarkable paper entitled Metaphysics ${ }^{49}$ (originally written in English), dated November 26, 1927, Sraffa expounds the purpose of his project. For expository reasons, I will divide the text into three parts. First, I will focus on the central part, which deals with the theme of language and translation. Then I will examine the last part, devoted to the relationship

\footnotetext{
${ }^{45}$ See Q.11, §47, p.1468. Izzo (2009) tends to emphasize, in Gramsci's concept of translatability, the feature of the uniqueness of reality. I prefer to say that, at the same stage of development, politics and culture provide different answers to problems that are substantially similar. On this see also Frosini (2010), p. 176.

${ }^{46}$ See Q.4, §46, p. 472. (engl. transl. vol. II, p. 196), but also Q.16.§ 9, p. 1854 et seq.

${ }^{47}$ See Frosini (2010), p. 176. Rightly, Frosini (ibid., p. 177) points out that "the criterion of translatability is able to highlight real links, independent and often discordant from those that appear to a formalistic perspective": the anti- formalism stems not from a presumed unity of the Spirit, but from the unity of theory and practice. The reconstruction of unity "is therefore always contingent and original, its reality is individual and factual, and it coincides with the actualization of politics." See on this Q.7, § 35 (engl. transl. vol. III, p. 184 et $s q$ ).

${ }^{48}$ See Sraffa Papers D3/12/11/35 but cf. also D3/12/4/12 .

${ }^{49}$ Sraffa Papers, D3/12/4 :14 -15. Quotes partial or total in essays by De Vivo, Garegnani, Kurz, Pasinetti and Porta, but with intent and interpretations different from those in this paper.
} 
between metaphysics and 'the cause of value'. Finally, I will deal with the opening sentences, dedicated to brief remarks on the relationship between analytical and historical dimension (an important issue on which I will return later).

It is terrific to contemplate the abysmal gulf of incomprehension that has opened itself between us and the classical economists. Only one century separates us from them: how can we imagine to understand the Greeks and the Romans? The classical economists said things which were perfectly true, even according to our standard of truth: they expressed them very clearly, in terse and unambiguous language, as is proved by the fact that they perfectly understood each other. We don't understand a word of what they said: has their language been lost? Obviously not, as the English of Adam Smith is what people talk to-day in this country. What has happened then?

I foresee that the ultimate result [of the book?] will be a restatement of Marx, by substituting to his Hegelian metaphysics and terminology our own modern metaphysics and terminology: by metaphysics here I mean, I suppose, the emotions that are associated with our terminology and frames (schemi mentali) - that is, what is absolutely necessary to make the theory living (lebendig), capable of assimilation and at all intelligible. If this is true, it is an exceptional example of how far a difference in metaphysics can make to us absolutely unintelligible an otherwise perfectly sound theory. This would be simply a translation of Marx into English, from the forms of Hegelian metaphysics to the forms of Hume's metaphysics. (Keynes ${ }^{50}$ to-day, 26.XI.27, has clearly outlined the divorce between English and Continental thought: the first descending from Descartes and Hobbes, two original geniuses, to Locke, Hutcheson and ultimately Hume; the second from Spinoza ${ }^{51}$ (did he say that of S:?) from Kant to Hegel: they always remained foreign to each other).

If this is true it also shows (or is it an exceptional case? In Physics it doesn't seem to be indifferent) how little our metaphysics affect the truth of our conclusions, and how the same truth can be expressed in two widely divergent forms. Our metaphysics is in fact embodied in our technique; the danger lies in this, that when we have succeeded in thoroughly mastering a technique, we are very liable to be mastered by her" ${ }^{252}$.

This very dense passage would require a more detailed examination than space allows. I will only mention some elements of context in order to facilitate its comprehension. The passage seems to me to say: a rigorous analysis of realities considered homogeneous leads to the same conclusion even in the presence of different patterns of thought (schemi mentali), emotions, terminologies (this complex is termed 'metaphysics'). In the texts of Marx and Engels, it is customary to use the term 'metaphysics' in a pejorative sense, closely related to the theory of fetishism ${ }^{53}$. As we will see in the next passage, no doubt is cast on the idea that 'metaphysics' may be a

\footnotetext{
${ }^{50}$ For the strong reactions of Keynes when he attempted to read Marx, and the considerations which Sraffa drew from them, see the two letters in April 1932 quoted in Marcuzzo (2004), p. 147, notes 77 and 78.

${ }^{51}$ In fact, as was shown later, the 'divorce' on a geographical basis indicated by Keynes (and, in a different way, by Hayek) between England and the European continent has many exceptions. Among these, the evidence of Hume's debt to Spinoza with respect to causality. See Scribano (2008).

${ }^{52}$ Italics added, underlining in the original text .

${ }^{53}$ See chapter 2 of The Poverty of Philosophy, entitled 'The metaphysics of political economy' and the passage of Engels's Anti- Dühring quoted by Antonio Labriola (1977) p. 214 et seq.
} 
possible hindrance to knowledge, and in this sense the term is used to criticize (à la Hume) Marx himself, who inconsistently with his own theory welcomes the idea of an (ultimate) 'cause' of value. The novelty lies rather in finding that the complex called 'metaphysics' is not only unavoidable but also necessary to render a rigorous theory 'living', assimilable and understandable in a particular cultural tradition. At the same time, such a theory may appear 'dead', unassimilable and incomprehensible in a country belonging to a different cultural tradition. The need for translation in order to overcome the lack of communication/understanding is not accompanied with an attempt to 'purge' the metaphysical features, as a positivist would have suggested, but entails replacing a German metaphysics (Hegelian, albeit 'turned upside down' by Marx) with an English (Humian) ${ }^{54}$ metaphysics, defined as "our modern metaphysics". Moreover, the question arises whether social sciences constitute an exception, since "it seems" that in physics different metaphysics do not lead to the same results ${ }^{55}$. Finally, with what may be overtones of self-criticism given Sraffa's previous adherence to the supply and demand apparatus, it is emphasized that the "technique" (formalism) at some point on the research path may drive the analysis instead of being its instrument.

The idea that 'metaphysics' can be consciously controlled or contained but not eliminated is present in the dialogue conducted by Labriola with Sorel in Talking of socialism and philosophy (Discorrendo di socialismo e filosofia). Sorel had posed the problem of how ${ }^{56}$ to "start in France a school of historical materialism." Labriola had replied that it would be best to start with "accurate translations of Marx and Engels, and whichever others may be necessary." And he added

"It is now thirty-seven years since I read German, and it always seemed to me that we, the peoples of Latin languages, are caught up in a strange confusion of our linguistic and literary skills whenever we translate from that language. What in German is lively, transparent, effective, becomes very often, for example in Italian, frigid, colourless, and sometimes even close to a slang [...]...it would be necessary...[...] for prefaces, notes, comments to offer surrogates to that easy assimilation process which is already implicit and of immediate use in the writings which are native to the country itself. Languages are not, in truth, the accidental variations of the universal volapük, and indeed they are much more than mere extrinsic means of communication and expression of the thought and the soul. They are conditions and limits of our interior being, which has for this, as for so many other reason, its own national ways and forms that are not mere accident."

\footnotetext{
${ }^{54}$ Sraffa's interest in Hume is demonstrated by his identification (along with Keynes) of Hume as the author of An Abstract of the Treatise, which appeared anonymously in London in 1740 and had been attributed to Adam Smith. See the preface, jointly written with Keynes, to the reprint of the original edition (Hume, 1938). On the history of the Abstract, cf. also Spencer (2003). As for Keynes, while his Treatise on Probability (1921) was regarded as an answer to Hume's theory of induction, his writings of the '30s, starting with the General Theory, indicate that he came to the humean conclusion according to which "it is not reason...the guide of life, but habit. It only moves the mind, in all cases, to assume the future conform to the past." See Andrews (1999), especially pp. 15-16 and Hume (1938), p. 678. I am not aware that this 'turning point' in the philosophical position of Keynes, challenged however by other authors, has ever been connected with Sraffa.

${ }^{55}$ I will return to this point later.

${ }^{56}$ See Labriola (1977), p. 197, May 14, 1897.
} 
And a little later, after pointing out that Engels used the word 'metaphysics' in a pejorative sense, Labriola wrote: "metaphysics...has some analogy with the distant origins of myths", adding:

"This kind of metaphysics...exists and perhaps always will exist... in the verbal and phraseological forms that are utterances of thought, because the language, without which we could neither reach the precision of thought nor formulate its expression, at the same time as it says something alters what it expresses, and has therefore always within itself the germ of myth. However deeply we go into the more general theory of vibrations, we will always say: the light produces this effect, the heat works in that way. We always have the temptation to substantivise a process, or the terms of it, or at least there is the risk of doing so."

The conclusion on this point was that this metaphysics "leaves its traces even in what in our times we proudly call science." 57

The following passage in Sraffa's note presupposes that distinction between 'real physical costs' and 'costs as an inducement, or sacrifice' that I mentioned earlier, and that is a watershed between the two alternative theories. As anticipated, Sraffa criticizes Marx for the presence of "some" metaphysical elements in the labour theory of value: in looking at labour as a (ultimate) 'cause' of value, he has lost sight of the concept of surplus, instead opening the way for the idea of labour as sacrifice. Furthermore, he placed the analysis on a level at the same time not observable and thus arbitrary, and 'naturalistic ${ }^{\text {, }}$. In fact, it became adjacent to conceptions based on the fetishism of the 'factors of production', including that very 'rough' (grossolana in Italian) conception proposed by J.B. Clark ${ }^{59}$, (although Sraffa points out that Marx does not believe ${ }^{60}$ that labour alone is productive of [use] value) and therefore he did not base the right to the whole product of labour on this, unlike some Ricardian socialists:

"The typical case of Marx's metaphysics is his statement that "only human labour produces (causes) values", "values are embodied human energy (crystallised)": there is no doubt that he attached to it some metaphysical meaning.

The extraordinary thing is that the same metaphysical notion is held by such an anti-Marxian as Cannan (Theories, p. 380).

The metaphysics of the modern economists is that "a commodity...is the embodiment of measurable efforts and sacrifices" (Marshall, Memorials, 126); on the same plane as Marx's "crystallised labour". And much more Clark's notion that marginal distribution being equal to product of each is "just". Clark's metaphysics is much more grossolana [sic] than Marx's: it is equal to Proudhon's, Hodgskin's etc. who believed (against Marx) that since labour produces the whole it must get the whole.

\footnotetext{
${ }^{57} \mathrm{Ibid}$, p . 212-13, May 24, 1897, italics added. In the last italics, I intend to underline the non-idealistic subjectivism of Labriola, as it is linked with the economic and social structure and with the cultural tradition.

${ }^{58}$ For a reconstruction of this aspect in the conception of Marx, see Lippi (1979).

${ }^{59}$ See Clark (1899).

${ }^{60}$ See for example Marx[1847] and [1875].
} 
All the inquiry about value has always been (and still is and probably always will be) a purely metaphysical quest. When the old economists asked for the "causes" or the "measure" of value, they really were looking — as in fact we are, under the illusion of our equations "determining" value - for the "nature" of value (it is not an accident, as Cannan elsewhere says that the word is in A. Smith title) in the same metaphysical sense in which we look for the nature of "matter" or of "mind". In fact, we want to "explain" in terms of familiar words or notions (i.e. to which we are used) the "new" thing that we meet; but when we got used to them (as now economists have with prices) we take them for granted and require no further explanation. The explanation has simply to be "satisfactory" that is to provide the accommodation suited for our mental habits, and prove restful to the mind - cool down the fever of quest and satiate the thirst for explanation".

The last part of this passage refers to an extract from the physicist Hertz's introduction to his book Principles of Mechanics of 1894, which Sraffa transcribed, probably in 1927-28. With undertones that recall the passage quoted above from Labriola, Hertz asked himself why we often hear it repeated that the nature of such notions as 'force' or 'power' is still mysterious whereas no one wonders about the nature of concepts such as 'gold' or 'velocity'. Hertz's answer is the following:

With the terms "velocity" and "gold" we connect a large number of relations to other terms, and between all these relations we find no contradictions which offend us. Therefore we are satisfied and ask no further questions. But we have accumulated around the terms "force" and "electricity" more relations than can be completely reconciled amongst themselves. We have an obscure feeling of this and want to have things cleared up. Our confused desires find expression in the confused questions as to the nature of force and electricity. But the answer we want is not really an answer to this question. It is not by finding out more fresh relations and connections that it can be answered, but by removing the contradictions existing between those already known, and thus perhaps by reducing their number. When these painful contradictions are removed, the question as to the nature of force will not have been answered, but our minds, no longer vexed, will cease to ask illegitimate questions ${ }^{61}$.

It is no coincidence that after the theoretical 'turning point' of the second half of 1927 Sraffa transcribed the passage just quoted from Hertz. With the progress of his analysis on value, in fact, he realized that within the marginalist framework the determination of relative prices was overloaded since relations of demand and supply were often contradictory with the mathematical properties of price relations.

\footnotetext{
${ }^{61}$ See Hertz [1894], p.7. Hertz's research program involves purging mechanics of metaphysical residues that surround non-observable notions. Newton and his successors suggested that the term 'force' conceals a 'causal agency' when, according to Hertz, we are dealing only with a mathematical relationship between mass and acceleration. To overcome this difficulty, Hertz, in the book quoted above, elaborates a presentation of the fundamental principles of mechanics in which the concept of force is wholly absent. On the importance of Hertz's conceptions for Wittgenstein, cf. Ginzburg (2013) and references cited therein.
} 
In an important note written between November 1927 and the early $1930 \mathrm{~s}^{62}$, Sraffa observes that the "general confusion" surrounding "all theories of value" comes from not being able to distinguish between "two entirely different types of questions and the universal attempt of solving them both by one single...theory." The first question concerns what determines the prices of different commodities exchanged "in a given market on a given instant." The second question asks instead what determines "the changes in the values of commodities at different times", for example in response to a change in the initial conditions, such as the imposition of a tariff or a tax, or a change in tastes or the introduction of innovations. "[Marshall's] theory of value - Sraffa notes — with its increasing and diminishing costs and marg[inal] utility, scissors, pillars and forces, can only be understood as an attempt to solve the first question in terms of the second."

In the manner of Hertz, Sraffa solves the "contradictions which offend us" through "a reduction in the number of relations" considered. In this case, the step back consists in the total elimination of the concept of "forces of supply and demand, ${ }^{63}$ and in the separation of the determination of wages and quantities produced from the determination of prices. In his price equations developed to answer the first question, Sraffa notes that "there is a causal connection (causa essendi) between the two sets of quantities", i.e. the real physical costs and values, and "the theory reproduces as a logical relation between two...concepts...the concrete causal relation between the two facts.",64

Pursuing the analysis of the confusions surrounding the issue of value, Sraffa writes ${ }^{65}$ : "A... disturbing element is that in the background of every theory of value is a theory of distribution" which frustrates any "continuous attempt at visualizing in the microcosm of any particular commodity a process which takes place in all commodities as a whole.." Sraffa is here taking a distance from his previous attempt to separate production and distribution on a partial equilibrium basis. "Often - Sraffa adds theories of distribution... are meant not so much as a means to analysing the actual process through which the product is distributed between different classes, as for

\footnotetext{
${ }^{62}$ Sraffa papers D3/12/7, quoted by Garegnani (2005), pp. 472-3.

${ }^{63}$ In a paper of 1955 that should be read in association with the notes of autumn 1927 already considered, Sraffa writes that the concepts of utility and marginal productivity usually presented as directly observable quantities in fact depend on hypothetical 'changes' so that, Sraffa writes, "a man from another planet...would never, no matter how searching, succeed in discovering the determinants of distribution. He could discover them by experiment, but never by observation". Criticizing Wicksteed for having asserted the actual existence of the marginal supply curve as part of the initial position, Sraffa commented: "This is nothing less than a declaration of faith in universal determinism, for nothing less can support the actual belief in the actual existence of a prescribed path which must inevitably be followed, whether by the consumer or by the producer, such as is described by the demand-and-supply curves" (my italics). See D3/12/42 Sraffa Papers, quoted in Rosselli and Trabucchi (2010), p. 125-6 and 130, and Ginzburg (2013).

${ }^{64}$ See Sraffa Papers D1/9:10, quoted in Kurz and Salvadori, p. 428, who, reporting the passage quoted in the text, appropriately also recall two of Sraffa's excerpts from the introduction by Hertz on the relationship between 'images' (or 'symbols') of external objects and their representations by means of 'simple relations'.

${ }^{65}$ Sraffa Papers D2/4.3.3-4. Italics added.
} 
showing either that the present system is wrong and should be changed, or that it is right and should be preserved. Thus an analysis of what is becomes a form of propaganda for what ought to be." It may be noted that this implicit reference to the famous 'is-ought' problem formulated by David Hume ${ }^{66}$ is here employed for a double critique, of the 'apologetic' marginalist formulation à la J.B. Clark and for the 'right to the whole produce of labour' interpretation of the labour theory of value by the Ricardian socialists.

This is the point to read the short, somewhat cryptic passage with which Sraffa starts the whole piece on translations of different metaphysics, from Hume to Hegel.

"In this theory it will be thought that the important part is the analytical and constructive. The significance of the historical side will be missed. And yet, this is truly important, that which gives us a real insight into the mystery of human mind and understanding, into the deep unknown relations of individuals between themselves and between individual and society (the social, or rather the class mind)".

Throughout the note we are dealing with here, Sraffa is confronting the difficulties of communication, both cross-cultural and across periods, which require to be translated, and in a thoroughly non-mechanical way. In claiming the importance of the theory that will be the subject of the book he is planning, he anticipates that the greater part of it will not be dedicated to the history of economic thought but will, rather, be analytical and constructive. He adds that this will entail an underestimation of the importance of the historical side. The adjective 'historical' (opposed here to 'analytical') seems to refer to the history of economic theories, but more generally to the relationship between individual and collective elaboration, and between the latter and the social-historical environment.

What is really surprising is that Sraffa believes that the historical dimension may provide "a real insight into the mystery of human mind and understanding" with a glance "into the deep unknown relations of individuals between themselves and between individual and society" ("the social or rather the class mind", not "class consciousness" as perhaps one would have expected). The first part of the passage alludes to some form (to be ascertained) of 'economic determinism', the second to a non-reductionist anthropology like the one depicted by Hume in the Treatise. It may be noted that it is the emancipation from the supply and demand apparatus that allows the inclusion in the analysis of behaviours and events that the previous analysis led to

\footnotetext{
${ }^{66}$ See Hume (1969) [1739-40], Book 3, section 1, p. 521: "In every system of morality, which I have hitherto met with, I have always remark'd, that the author proceeds for some time in the ordinary way of reasoning, and establishes the being of a God, or makes observations concerning human affairs; when of a sudden I am surpriz'd to find, that instead of the usual copulations of propositions is, and is not, I meet with no proposition that is not connected with an ought, or an ought not. This change is imperceptible but is, however, of the last consequence. For as this ought, or ought not, expresses some new relation or affirmation, 'tis necessary that it shou'd be observ'd and explain'd; and at the same time that a reason should be given, for what seems altogether inconceivable, how this new relation can be a deduction from others, which are entirely different from it".
} 
ignore (including, for example, the possibility to take into account effective demand and violations of Say's principle, and therefore situations of non-temporary unemployment). For Hume, - Lecaldano wrote - social man is "predominantly made up of instincts, habits, passions, and the role and scope of reason are very restricted". He added: "these passions and instincts are not always fully original since, in reconstructing their genetic process, the investigator of human nature outlines the mechanisms that have led to their constitution, explaining through simpler procedures the conventions and habits that underlie an intellectual activity. Moreover, the passions, instincts, customs and habits, despite being artificial, derive from a process so deeply buried at the root of the formation of human culture that they are presented now as completely natural." ${ }^{, 67}$ Since habit is much more malleable than an innate idea or abstract reason, it provides tools for justification and explanation not only of immobility, but also of social transformation.

These issues prompt us to wonder what idea Sraffa entertained of historical materialism. Before attempting to deal with this aspect of his conceptions, albeit on a provisional basis, it may be useful to come back to the meaning of the 'theoretical turning point' of autumn 1927 in the light of the document 'Metaphysics', of which seems to me difficult to underestimate the importance.

3.3. The reconstruction proposed by Garegnani, as given in the foregoing pages, enables us to speak of a 'turning-point' since it underlines the movement from a substantially Marshallian interpretation of classical political economy - that Sraffa entertained when he commenced writing the pre-lectures ${ }^{68}$ - to the rediscovery of an alternative theoretical path based not on the 'psychic costs' but on the 'material costs', that opened the way to the concept of surplus. Those who have denied the existence of a theoretical turnaround or have minimized its importance have counterposed a Marxian path to the anti-Marshallian one reconstructed by Garegnani, and have used a variety of arguments to do so. However, it is interesting to note that those who have chosen to highlight the influence of Marx have completely ignored the documents analyzed by Garegnani, and especially the pre-lectures: for this reason, the contrast itself between 'psychic costs' and 'physical real costs' that plays such an important role in Sraffa's papers of this period has no role in these reconstructions.

For that matter, Garegnani himself, as I have recalled, in maintaining that ${ }^{69}$ "before his theoretical break-through, Sraffa certainly had a good knowledge of Marx" but had doubts as to his scientific worth - especially as regards the labour theory of value - admits the influence of classical authors in Sraffa's theoretical turn-around since he goes on to say that:

\footnotetext{
${ }^{67}$ See Lecaldano (1991), p.78. It may be recalled that for Hume also the belief, or category, of cause and effect, is attributable to passions or instincts.

${ }^{68}$ After the war, Sraffa forbade any translation into English of his article of 1925. This prohibition originates in his abandonment of that youthful 'marshallian' interpretation.

${ }^{69}$ See Garegnani (2005), p. 485, my italics.
} 
It is only after his independent rediscovery of what he saw to be Classical economics, made along his very particular path of a critique of Marshall's 'real costs' and the confrontation with them of 'physical real costs' inspired by Quesnay and the Classical authors in a general sense, and after the resulting 'equations' that Sraffa came to recognize a new Marx... and this stimulates him to dive into reading (or re-reading) his works.

A reflection starting out from the critique (self-critique) of the Marshallian interpretation of the classics is compatible with the hypothesis that in treading his "very particular path" Sraffa arrived at Quesnay (and Petty) through a French translation of the Kautsky edition of Marx's Theories of Surplus Value ${ }^{70}$.

Sraffa's knowledge of this work (exactly how deep at this stage is unclear) may account for the scheme of the book he intended to develop. This would, at least initially, have been a 're-writing' of the History of Economic Doctrines (or Theories of Surplus Value) updated with the analysis and discussion of marginalist theories of value and distribution. In this work, the "restatement of Marx" would have come about after replacing quantity of labour with commodities (subsistence goods, means of production); as mentioned before, labour was a concept considered by him at that time (also in Marx) as susceptible of metaphysical elements, and an ambiguous drift /shift towards the Smithian concept of "toil and trouble".

At least until $1929^{71}$, as we know, Sraffa was hesitant or reluctant to employ the concept of 'quantity of labour' or 'hours of labour' in the theory of value. This hesitation or reluctance would be incomprehensible if we lost sight of the risk, explicitly feared by Sraffa ${ }^{72}$, of returning to the concept of labour as "one of the factors of production"; and this reluctance, too, originates from his moving away from the Marshallian interpretation of costs. For that matter, if he had not ultimately seen that both quantity of goods and quantity of labour, from the analytic point of view, could be considered as given quantities independently of prices and rate of profit, he could not have foreseen that the path would end in "a restatement of Marx". "Different metaphysics', once translated, might lead to equal results: the formulation of Petty and his followers, deeply influenced by Bacon, with its distinction between efficient causes

\footnotetext{
${ }^{70}$ Kurz (2012), p. 1547, note 18, remarks that Sraffa read this work in the summer of 1927. In the diary entry of 27 November 1927, alongside the names of Petty and Quesnay among others, Sraffa refers to an article by Cunningham (see Kurz and Salvadori), 2005, p. 416, note 3. In this article, on which I will return later, William Cunningham, important exponent of the English Historical School and fiercely antineoclassical, contrasts "Petty's approach" based on 'a solid foundation of fact' "with Marshall's description of economics as the "science of measurable motives" (Kurz and Salvadori, 2005, ibid., p. 417).

${ }^{71}$ See Kurz and Salvadori (2005), pp. 422-423.

${ }^{72}$ See D3/12/11:64 cited in Kurz and Salvadori (2005), p. 418. "It is the whole process of production that must be called 'human labour' and thus causes all product and all values. Marx and Ricardo used 'labour' in two different senses: the above and that of one of the factors of production ('hours of labour' or 'quantity of labour' has a meaning only in the latter sense). It is by confusing the two senses that they got mixed up and said that value is proportional to quantity of labour (in second sense) whereas they ought to have said that it is due to human labour (in the first sense: a non-measurable quantity, or rather not a quantity at all”.
} 
and final causes ${ }^{73}$, and by Hume with the is-ought distinction, might ultimately appear consistent with Marx's formulation, once it had been purged of Hegelian language and metaphysics.

In the framework of an otherwise useful contribution, De Vivo (2000) and Gilibert (2003) have proposed a reconstruction (different from Garegnani's) of the path travelled by Sraffa as he began to construct his equations. They take no account whatever of the writings of 1925 and 1926 and the 'endogenous' path that led to the contrast between 'psychic costs' and 'physical real costs'. They detect, instead, the influence exerted by the conceptions of Quesnay, through Marx, in construction of the equations.

This would be acceptable, bearing in mind what was said above. However, they make a big leap when they identify Quesnay's conceptions with Marx's reproduction schemes, and thus they find Sraffa's equations underpinned, not by a possible indirect influence from the conceptions of the Physiocrats and of Petty directly or indirectly through the History of Economic Theories ${ }^{74}$, but by the direct influence of the equations in volume II of Capital. Yet Sraffa does not seem to have read volume II before 1928. In addition, as Gilibert himself acknowledges ${ }^{75}$, "when writing down [the reproduction schemes], Marx was not concerned with the problem of relative values. He was primarily interested in investigating the physical proportions among industries, which were necessary for an orderly development of capitalist production." Even should it emerge that Sraffa had read volume II at that time, it would still be true that his ability to draw inspiration from those schemes for the different problem of determination of relative prices could only be fully understood by starting from his moving away from his previous 'Marshallian' interpretation of the classics.

In actual fact, the point of contact between the reproduction schemes and the 'equations' of Sraffa lies only in the introduction, in both cases, of the hypothesis of reproduction of the economic system. This would be a non-crucial element in the distinction between alternative theories, if it did not probably suggest a deeper matter

\footnotetext{
${ }^{73}$ In an annotation of April 1928, Sraffa writes: “"Efficient causes' are facts of the past that act on the present: 'final causes' are facts of the future that act on the present. The existence of the latter is at best dubious and they are better called 'illusions'. The classical P.[olitical] E.[conomists] dealt only with the first sort of causes, i.e. of 'material things' that have existed in the past. Modern economists deal with the second class, i.e. hopes for the future, such as utility, abstinence, disutility, etc; these things, it must be noticed, refer only to the foresight of future acts" (see Kurz and Salvadori, 2005, p. 427, note 16 and D3/12/10:61(1)).

${ }^{74}$ See also Arturo Labriola (1922), pp. 208 et seq., a volume read and annotated by Sraffa in this period. Labriola had read and partly summarized the Theory of Surplus Value, remarking, for example (p. 214): "Physiocracy is supported by a great deal of truth... [The physiocrats maintained] that consumption is not merely destruction of utility, but of things in themselves, and therefore their reproduction is the indispensable condition of every and any further utilitarian adaptation of things to man. The foundation of truth underpinning all physiocracy can be encountered in all those theories that consider materiality as an attribute of goods". And further on, p. 217: "...we see that the problem of value is posed in Classical Economics as a means to solve the problem of the net product. But the problem of value in Vulgar or Apologetic Economics and in Exact Economics arose in a quite different way".

${ }^{75}$ See Gilibert (2003), p. 31, note 3.
} 
for dissent. The consideration of the first chapter of Production of Commodities on the determination of relative prices for economies in a self-replacing state without a surplus, together with a well-known passage $\mathrm{e}^{76}$ in the 'References to the Literature' in the appendix, was frequently interpreted ${ }^{77}$ as if the needs of reproduction were a characteristic per se able to distinguish the classical scheme from the marginalist one. An echo of this idea can also be found in the conception that detects in the two schemes a supposed contrast between 'vision of reproducibility' and 'vision of scarcity' (as though the two schemes did not differ in their definition of the problem of scarcity and ways of dealing with it). But if the differences of 'vision' manifested in the formulation of the price equations, it would be impossible to use the same equations, as did Sraffa in 1960, to illustrate, in the context of the theory of value, the classical scheme and simultaneously to criticize the marginalist theory. As Ravagnani (2001), p.357, observed, it is true that "historically..the study of the conditions allowing for repetition of the circular process of social production has been crucial".. "for a first definition of the key concept of surplus" in physical terms and thus "for the formation of the classical standpoint on value and distribution". But a closer look at the actual content of the first chapter of Sraffa's book - and in particular to an important qualification included in a Sraffa's footnote ${ }^{78}$ - leads Ravagnani to conclude (p. 358) that "the classical determination of relative prices is in fact independent of the existence of a physical surplus product, and applies equally well to situations characterized by negative net outputs of means of productions, i.e. to circumstances under which the reproduction of the economy... is actually impossible". The crucial element that distinguishes the two theories is not the reproduction of the production cycle nor the existence of the surplus, but the circumstances surrounding its formation and distribution, and hence what is taken as given in the measurement of the net product by means of the theory of value.

Also Kurz and Salvadori (2005) and Kurz (2012), like the authors discussed above, give secondary importance to the 'endogenous' path of withdrawal from the Marshallian interpretation of the classics, making use of an exogenous element - in this case a pre-existing general philosophical option, 'objectivism'. In their view, this option was dominant in Sraffa's analytical reflection, influenced by his keen interest in the recent developments in science, especially physics, and provided a precise "natural scientific point of view" for analyzing social systems. Which paints Sraffa as a positivist materialist dominated by 'scientism'.

\footnotetext{
${ }^{76}$ Sraffa writes (1960), p. 93: "It is of course in Quesnay's Tableau Economique that is found the original picture of the system of production and consumption as a circular process, and it stands in striking contrast to the view presented by modern theory, of a one-way avenue that leads from 'Factors of production' to 'Consumption goods"'.

${ }_{77}^{77}$ For a bibliography and a critical discussion of this literature, see Ravagnani (2000) and (2001).

${ }^{78}$ See Sraffa (1960), p. 5, note 1. Sraffa points out that the determination of the relative prices does not presuppose the system's being in a self-replacing state, but a weaker condition, viability. Ravagnani (2001), p. 358-8, observes: "Provided Sraffa's viability condition is fulfilled, the classical theory of value thus appears to be entirely open as to the direction in which the individual sectoral outputs may tend to evolve. Indeed, this property is one aspect of the separation between the analysis of prices and that of quantities, which Sraffa brought to the fore as a typical feature of the classical approach".
} 
But it seems to me that the documentation collected by Kurz and Salvadori, however useful and interesting, is susceptible of a different interpretation from the one they propose, if collocated in the thread of Sraffa's intellectual development. First and foremost, it must be clear that in Sraffa's texts the terms 'objective' and 'subjective' are always used in a relational, culturally 'situated' sense, never in an absolute sense. In the sense that what is considered to be 'objective' is always defined in opposition to a precise definition of what is considered 'subjective' (useful here is the contrast between 'real material costs' and 'psychic costs' of homo ceconomicus). If we lose sight of this non-absolute meaning, Sraffa's position, labelled as 'objectivism', comes to be wrongly equated with the philosophical stance known as 'physicalism' (a form of metaphysical naturalism often associated with Otto Neurath of the Vienna Circle), that holds that only 'physical things' exist ${ }^{79}$. According to this formulation, any knowledge whatever must of necessity be retraced to statements about physical objects and the language of physics would be the universal language to employ in all sciences.

I do not think this was Sraffa's position. Faced with a discipline that, even while claiming to be scientific, bases its foundations on 'final causes' and 'illusions', he contrasts it with a firm appeal to the observation of reality - making use also of the British philosophical tradition (Bacon and Hume). The material datum is taken as the starting point of economic analysis, though without its being ontologically exhaustive of the knowable and its point of arrival. In this perspective, the nature of Sraffa's materialism (and its eventual developments) remains a matter to be investigated ${ }^{80}$, whereas labelling it 'objectivism' settles it without suggesting or leaving any possibility of further investigation.

To the foregoing remarks we must add that, as Garegnani observed ${ }^{81}$, if Sraffa's reflection had been driven by 'objectivism', the Marshallian interpretation of the classics could already have achieved the 'objectivist' goal with no need for further investigation.

We now turn to the interest shown by Sraffa, in this feverish period following the 'turnaround', in the writings of scientific authors like Poincaré, Hertz, Picard and others. Should we view as the expression of a positivistic faith in the general progress of

\footnotetext{
${ }^{79}$ For this collocation of Sraffa's thought see, for example, Marion (2005), especially pp. 391-2. The author admits that "there is no evidence" that Sraffa was aware of the discussion under way within the Vienna Circle, but makes use of the interpretation of 'objectivism' proposed by Kurz and Salvadori and the fact that the already mentioned Whitehead's book Science and the Modern World (1925) was "read and annotated carefully" by Sraffa in order to include it, together with Wittgenstein, in the category of 'physicalism'. In the first place, it seems quite inappropriate to put Whitehead in that category; secondly, Kurz and Salvadori (2005) themselves (p. 428) note that Sraffa made critical annotations in the margin of his copy of Whitehead, from which it is deduced that he "generally felt that Whitehead's concept of 'materialism' was too narrow and too much focused on obsolete orthodox materialism". From the context, one deduces that Marion holds - probably starting from a post-modernist theoretical perspective - that everything that is not 'idealistic' (considered equivalent to 'subjectivist') can be defined as 'physicalist'.

${ }^{80}$ On this point see $\$ 4$ below.

${ }^{81}$ See Garegnani (2005), p. 485, note 31.
} 
science, and therefore evidence of Sraffa's option for an 'objectivist' philosophy? Or should we wonder what specific analogical role was played by these researches at that moment in history and in the critical-reconstructive path of Sraffa's thought beginning in November 1927? When he started his 'pre-lectures' he was still in the Marshallian phase and invoked the general progress of science in order to purge the theory of value of metaphysical content; but it seems to me no mere accident that after the 'turningpoint' the physics texts annotated by him have to do with authors dealing with the crisis in classical mechanics ${ }^{82}$.

In the previous pages we have recalled the link between certain of Sraffa's reflections and the research of Hertz. In a book bearing Sraffa's annotations, Poincaré emphasizes the need to re-examine the postulates (the conventions) of traditional physics in the light of further experimental observations, and in the chapter devoted to 'Energie et Thermodynamique ${ }^{83}$ he reiterates that the problems encountered by classical mechanics have led certain authors "to prefer a new system called energetics".

Other annotations concern writings expounding quantum theory by Heisenberg, Schrödinger, Dirac et al. In the 1920s physics may have been admired and envied because, unlike economics, it was able to "change its own directive principles" whenever those same principles had been "contested by a group of perfectly contrary experiments or observations suggesting that the experiments did not tally with the principles". So said Arturo Labriola in the concluding chapter, titled "The crisis of the principles in political economy", of his above-cited book ${ }^{84}$.

In the 1940s, the philosopher Eugenio Colorni wrote in a more articulated way ${ }^{85}$ :

I consider..."the freedom of definition" to be one of the greatest advances in contemporary science. This freedom has been used differently by physicists and economists. The physicists are always determined that their definitions be such that the reality of the experiment may be entirely contained therein; and in order to achieve definitions that most precisely match the essential characteristics of what we see, touch, measure and experience, they are ready to abandon the most fixed laws, the concepts that were hitherto the surest: the

\footnotetext{
${ }^{82}$ Classical mechanics was the basis for Pareto's general equilibrium equations. Pareto began his Cours d'Economie Politique with the statement "Economics is a natural science".

${ }^{83}$ See Poincaré (1902), pp. 134 and 148. See in particular chapter IX, on the conditions that permit generalizations and on the role of experience in checking the plausibility of hypotheses. "Every generalization-he writes, p. 172-assumes to a certain extent the belief in the unity and simplicity of nature". On these issues, see also Arturo Labriola (1921), pp. 328-336.

${ }^{84}$ See Arturo Labriola (1921), pp. 360-361. According to Kurz (2012), p. 1547, note 16, "At the time the more popular works of physicists (and other natural scientists) were widely read by social scientists, and Sraffa was no exception to this." Kurz confines himself to remarking that Sraffa "in all probability came across...the works of Hertz and Helmholtz when reading Labriola".Labriola refers to physicists who were engaged in breaking with classical mechanics, and this in the context of his specific criticism of mathematical (marginalist) economics. Kurz makes no mention of this.

${ }^{85}$ See Colorni (2009), p. 341, italics in the text. Colorni's article is titled 'Dello psicologismo in economia' ('Psychologism in economics') and discusses in particular Robbins's ideas.
} 
notions of equality, simultaneity, space, causality, the laws of conservation of energy, etc. ... The experiment...is the starting-point for changing all definitions, and no matter whether this entails the wholesale collapse of classical physics - provided that it emerges that the new building under construction is able to contain more of the world... Economics, instead, does exactly the opposite. Its central concern is to preserve received ideas, whatever may happen to the concrete facts to which these laws should apply. The principle of marginal values, the law of demand and supply exist.

According to Kurz and Salvadori (2005) and Kurz (2012), Sraffa's annotations to the scientific writings cited above would justify ascribing to him a position of 'absolute objectivism'. As I see it, however, these notes point to a specific interest within the project for reconstructing economic theory. What is of relevance is the way in which physics sought, through observation (and experiments), to rebuild itself after the crisis in classical mechanics and to address a variety of topics, including causality, in new terms. Kurz and Salvadori are undoubtedly correct in stating that Sraffa's opinions on these subjects probably altered between 1927 and 1931. But from what has been said we may feel serious doubts with regard to their claim that Sraffa, after reading and annotating works of physics with the greatest interest, must for this reason have entertained, up to 1931, a "natural science point of view", which, as we shall say, has a precise meaning. As he wrote in 1931, it is for him equivalent to embracing the Leibnizian principle of 'sufficient cause' that refers to the idea that any cause is necessarily followed by an effect, and that every effect is necessarily associated with a cause.

3.4. The position that I defined as 'absolute objectivism' — wrongly attributed, in my opinion, to Sraffa - is characterized by two elements, namely the acceptance of "the point of view of natural science", and the limitation of the scope of scientific analysis to material entities, to 'things'. In the preceding pages I have argued that it does not seem legitimate to ascribe to Sraffa the point of view mentioned above simply because, in the crucial period of his theoretical turning-point, his notes reveal a great interest in scientific papers, particularly in the field of physics. But what is the relationship between the abandonment of the Marshallian interpretation of the classical economists and the way to address the problem of causality in social analysis? On this point, it seems to me, the 'absolute objectivism' position has nothing to tell us. In addition, while that position is at first sight consistent with the first two sets of Sraffa's equations, in which the economic system is in conditions of simple reproduction or with a surplus but with a wage of specified composition, it is instead unable to account for the third system of equations, unless in a merely formalistic manner ${ }^{86}$. In the third set of

\footnotetext{
${ }^{86}$ According to Kurz and Salvadori (2005), p. 424, Sraffa's introduction of the concept of labour as a measurable magnitudo "served only a single purpose: that of providing a basis on which wage payments are made". See on this Perri (2010), p. 39, note 2.
} 
equations, though, as pointed out by Perri ${ }^{87}$, "wages change radically both their function and nature. Here, they are not determined by the level of subsistence and therefore they do not serve the purpose of determining the physical costs of production but, rather, become part of the income or surplus. Indeed, only when labourers succeed in taking part in the distribution of surplus do they appear as a social subject in the 'core' of the theory". As several commentators have observed ${ }^{88}$, in some notes written in the early 40's commenting Bortkiewicz, Sraffa considers the hypothesis of wages as given inventory of commodities for subsistence, "useful... as a starting point" but "the fodderand-fuel aspect of wages... is still tarred with commodity fetishism".

Faced with these and other difficulties, the 'absolute' position is forced to admit that the definition of 'objectivism' "changes over time" but is unable to specify why, in which direction and how.

I will mention briefly here three elements that, in my opinion, should be taken into account on the issue of objectivism. The first relates to Sraffa's particular working method. The complexity of social reality forces us to construct representations ranging from simple to complex. The synoptic representation of economic systems that maintain some basic conditions (viability, existence of a net product) but become progressively more complicated is not addressed to highlight a historical evolution, or suggest improbable genealogies, but to help us to see complex structures as modifications of a simple structure. This is the morphological method, that we find also in Marx and, before him, in Goethe ${ }^{89}$. Of course this does not mean that Sraffa had in mind from the outset all the developments of his analysis. We know that it had moments of interruption in the '30s and acceleration, with detailed readings of texts by Marx, in the early '40s. But it would be equally wrong to consider the second system of equations as that which characterizes the 'essence' of Sraffa's contribution, and thus the fundamental point of arrival of his thinking, with the exception of minor formal adjustments and additions.

The other two elements concern the two alternative projects that Sraffa conceived after the theoretical turning-point. As mentioned, the first was an account of the history of economic thought, "from Marshall to Marx, from disutility to material

${ }^{87}$ Cf. Perri (2010), p. 41. He shows the implications of the adoption of the labour employed in the production of the net product as the unit of measurement of price. I wonder whether his idea of prices "macrofounded" (p.58) or that of a social labour-value theory (p. 39, note 2) will not unintentionally reintroduce misleading elements of continuity (and thus confusion) between the interpretation given, on this basis, to the third set of equations, and the labour theory of value, understood as a theory of exchange relationships. I don't think it is useful to employ the term 'foundation' when we are faced with the choice of a price numéraire. As for the 'unveiling' of commodity fetishism to counter the 'vulgar opinion', one may achieve the same purpose through the reduction of prices to dated quantities of labour.

${ }^{88}$ See Perri (2010), p. 46 who quotes papers by Bellofiore (2001) and Gehrke and Kurz (2006).

${ }^{89}$ As is well known, the scheme 'from simple to complex' is utilized by the second Wittgenstein in the idea of linguistic games. The articulated linguistic structure is seen as a complication of a simple form. Moreover, according to Wittgenstein (1993) "the basic form of our game must be such that in it there is no room for doubt". On this see Voltolini (2006), p. XIII-IV. On the morphological method and references to Goethe, see Andronico (1998) and Ginzburg (2000). On the possible risk of essentialism that might arise from the importance granted to the basic form, a risk against which Wittgenstein himself warned, cf. Voltolini (2006), p. XVII. 
costs". The second project, contained in the document entitled 'Metaphysics' dated November 1927, in proposing a translation from Hegelian metaphysics into Humian metaphysics pointed out that the account would be "analytical and constructive" and not historical. We know that the second alternative eventually prevailed, even if the 1951 introduction to Ricardo and the References to the Literature in Appendix D of the 1960 book contain traces of the initial historical design. I believe that the two alternatives are well represented by the names listed in Sraffa's pocket diary on 27th November, 1927. We find on the one hand Petty and the Physiocrats, on the other Cunningham.

Already Arturo Labriola (1921) in a book mentioned earlier that alternates insightful observations with confused arguments, tried to draw a quick sketch of the history of economic thought that 'upgraded' Marx's History of Economic Theories to take into account the views of the marginalist economists. He argued that whoever "intends to proceed towards economic reality will necessarily be led to treat Economics as science not of the individual in Society, but of society in the Individual" (p. 40), while the mistake of starting from the individual conscience "is a basic premise of contemporary Economic Science" (p. 61). Labriola observes (p. 240) that "for the contemporary economist the problem of value is primarily or essentially a problem of exchange ratios" while for the classical economists, from the Physiocrats to J.S. Mill, this problem was "certainly secondary". Starting with the Physiocrats" ${ }^{90}$, the basic question was: how and where is the surplus formed, and to answer this question Ricardo (p. 240) "must measure simultaneously all commodities, express their value in terms of a universal standard that allows him to have an absolute figure to which the value of all things would be referred." Labriola (who accepted the solution of the determination of the rate of profits at the aggregate level proposed by Marx in the third volume of Capital) concluded (p. 239) that "the Ricardian system will always be the subject of the oddest misunderstandings if it is not referred to its natural filiation, the system of the Physiocrats". In the two final chapters, Labriola pointed out - in contrast to the unconventional questioning of basic principles in the writings of physicists like Poincare and others - the detachment from experience of contemporary economists. To this effect, he mentioned both the use of a "fantastic psychology", scientifically discredited, and the formalism of an economics reduced to applied mathematics, "whose only constraint is to satisfy the laws of thought to the exclusion of any internal contradiction" (p. 330-331). The position expressed by Arturo Labriola, on the whole, expressed ideas in part not far from those that led Sraffa to move away from Marshall's interpretation of the classical economists and then suggest, approximately, an index of the topics that could be included in the planned book on the history of economic thought. But the 'pure theory' perspective proposed by Cunningham, though not inconsistent with the previous one - since it, too, was starting, also from a methodological point of view, from Petty and the Physiocrats - was much more radical and, as we know, eventually prevailed: a choice that exercised an important influence

\footnotetext{
${ }^{90}$ For a Labriola's more detailed study on Quesnay and Physiocrats, see his Laurea Thesis (Arturo Labriola 1897), with a preface by his supervisor, Maffeo Pantaleoni.
} 
on Sraffa's subsequent research strategy and, above all, on the presentation of its results in Production of Commodities by Means of Commodities .

In the essay "A Plea for Pure Theory" (1892), Cunningham says (p. 25) that "nothing can not be more important at present than to reach some definite agreement on the relation of economic theory to the empirical study of economic phenomena". He strongly rejects the idea, for which he evidently had been blamed, that it was his intention "to discard theories": on the contrary, "pure economic theory can supply an instrument of study which no investigator could not neglect without serious loss. The economic historian must have... his work much simplified for him by the progress of pure theory". But what does Cunningham mean by "pure theory"? It is "an instrument of study" "for clear thought and accurate expression" (p. 38). For example, in the case of exchanges, in a "pure theory of economics" "every possible kind of exchange may be analyzed and described". Cunningham goes on to say: "In the science as thus suggested there has been no mention of causes or of laws of causation among phenomena. To my mind the attempt to treat economics as a science of causation has been most unfortunate and has introduced hopeless confusion". "As a pure science, economics has nothing to do with succession in time, or with 'causes' and motives. All these are matters for empirical investigation, to be sought for by empirical methods. The true analogue for pure economics lies with pure logic: while the one investigates the process of thinking and classifies its various forms, so the other investigates the process of exchanging and analyzes its different forms. The analysis of either process can go on without any consideration of 'causes"'(p. 30). What makes the conception of 'causes' 'inappropriate' because 'inadequate' in the case of economic investigations is "the interaction of 'causes'. Economic phenomena are part of the complicated social life of the world, and they are influenced by all sorts of distinct forces" (p. 36, italics added). Implicitly hinting at the distinction between nomothetic and idiographic approaches proposed by Windelband, Cunningham writes that in the social world "we do not need to suppose an unvarying regularity of sequence, we can take account of and try to explain events which are not precisely similar to any other events. We may deal with economic phenomena as generally controlled by human beings - their felt needs, their aims and aspirations, and we can give an explanation of any event when we detect the reasons to which it was due. In regard to the phenomena of physical nature, this course is not open to us... Our best course is to observe the antecedent conditions, and to note such of them as are invariable... But in economic investigation we deal with man as related to physical nature; we can detect the means that influence him even in unique action, and we do not render our explanation more satisfactory by formulating it in terms of invariable sequence, which are the best we can apply to causation in purely physical spheres" (p. 34, italics added). Cunningham goes on to describe what seems to him "the very kernel of the difference between the historical school and the normalists", a term that includes those who, like Marshall, in addition to being prone to generalizations, define "economics as the science of measurable motives". "Economic theory to the normalist is a theory of economic 'causes', while to the historian it is an 
instrument for describing and analyzing, and thus helping to explain, economic phenomena." "What is to be our starting point?" asks Cunningham. And he continues:

If we begin from events, and work back to the conditions that produce them, we start with what is observable, and can be described more or less accurately. This was a point on which Sir William Petty laid stress. His Political Arithmetic had to do with external phenomena, and so there was a possibility of collecting definite observations, and laying a solid foundation of fact. But when we start from motives, we lose all this advantage. What actually weighs with a man and determines him in any course of conduct, is not a thing we can observe; in any particular case we can only guess at it... Motives are not obvious, and we are not unlikely to be mistaken about them. If this is true about any particular man at any particular time, it is not clear that our generalization as to what the average man will do is sound as a matter of fact, though Senior appeared to think that economics was a positive science reared on this basis. We shall surely advance most satisfactorily if we start from what is observable and work towards the unknown, rather than if we begin our explanation of facts with motives which we cannot directly observe and about which we only guess. The historical procedure has the advantage that it works from ground where accurate observation is possible, and therefore rests on a firm basis, so far as the treatment of actual events is concerned. (p.35, italics added)

Cunningham's conclusion is that "the method of procedure which is best adapted for accurate observation and for thorough explanation is also the method which is least likely to generate confusion". This confusion stems from having formulated their results in the form of laws, seeking "mechanical analogies" (p. 41) in economic phenomena. "It is vain to try and recast the study [of economic phenomena] after the model of physics, in the hope of inducing the physicist to pursue it; he is not beguiled by the imitation" (p. 38).

Behind the arguments of Cunningham — and of Petty himself — in favour of a "pure theory" stands Francis Bacon" (not Otto Neurath). In the Advancement of Learning, Bacon warned against committing the frequent mistake of mixing final causes with efficient causes: "for the handling of final causes, mixed with the rest in physical inquiries, hath intercepted the severe and diligent inquiry of all real and physical causes,

\footnotetext{
${ }^{91}$ Petty's debt to Bacon is well known, and was widely recognized by himself (see Roncaglia 1985). On the other hand, even Bacon's debt to Machiavelli, as has been pointed out by Luciani (1947) and others, extends well beyond Bacon's famous acknowledgement ("we are much beholden to Machiavel and others, that write what men do and not what they ought to do"). It is possible that the link between Petty and Machiavelli with regard to some economic ideas suggested by Sraffa in response to a question of Gramsci had, underlying it, the hypothesis of an indirect relation, i.e. the mediation of Bacon. Sraffa's opinion was solicited by this specific question of Gramsci: "One may wonder if Machiavelli had economic theories: one will have to see if the essentially political language of Machiavelli can be translated into economic terms and to which economic system it can be reduced". See Gramsci (1975), Q. 13, p. 1575 and Gramsci and Schucht (1997), pp. 946 and 990. As far as Cunningham is concerned, Bacon's influence can be traced also in the refusal of contrasting induction and deduction. For Bacon, the methodized use of induction is an open ended process in which induction and deduction interplay in the light of new experiments and results. Cf. Bacon (2004), Aphorisms 103-105, pp. 161-163 and Aphorisms 117-118, pp. 175-177. On Bacon's philosophy of science see Hesse (1968), in particular p. 131-2.
} 
and given men the occasion to stay upon these satisfactory and specious causes, to the great arrest and prejudice of further discovery" ${ }^{\prime 2}$.

\section{Sraffa, Marx and Gramsci on the two materialisms}

I shall here take a brief look at two notes written in Italian in 1942, originating from reading a well-known passage from The German Ideology by Marx and Engels.

February 20, 1942

When one says that being determines consciousness, one does not mean to assert a (causal) relation between two universals. This would make no sense, because a causal relationship can hold only between particulars: to state a relation between universals means that this relation always holds good between pairs of particulars which compose the pair of universals - but not between the two members of this universal pair itself. Moreover, the relation of determination is a special form of the relation of causality: there must be a correspondence (for example, a similarity) between two members of the relation, such that one can assert a specific law, which allows one to recognize/identify the cause, given the effect (or vice versa); not an abstract causality which in each particular case can only be known a posteriori (for example the 'causes' of an unforeseen, and perhaps even unforeseeable event [chance, accident]) .

Thus, between a mode of production and the ideology which corresponds to it there is a relation of determination, a similarity. But when the ideology becomes a cause of change in the mode of production, there is no similarity whatsoever between the old ideology and the new mode of production - it is an abstract cause, but one cannot say that it determines it (? It is a 'causa essendi', but not a 'causa cognoscendi').

\section{May 26, 1942}

An example of this relation of determination is the relation between bodies and their shadows. The body determines the shadow in the same sense in which being determines consciousness: and there is no reciprocity. But then the shadow is also a material object and can itself be the cause of other things, for example a tree casts a shadow, and this causes a mushroom to grow. However there is a determination, a similarity, between the tree and its shadow, which does not obtain between that shadow and the mushroom: in this latter case there is, rather, a 'similarity' or relation between shadow and mushroom — but not between this shadow and its mushroom, but between shadows in general, any shadow. Furthermore, Marx says (in The German Ideology.. [English Translation p. 42] about ideologies (morals, religions etc.) and the corresponding form of consciousness: "They have no history, no development, but men, developing their material production and their material intercourse, alter, along with this their real existence ${ }^{93}$, their thinking \& the products of their thinking. Life is not determined by consciousness, but life that determines consciousness.' The same, identically, is valid with regard to bodies and their shadows: the former have their own

\footnotetext{
92 See Bacon (2000) [1605], p. 86.

${ }^{93}$ Italics added.
} 
movement and their own history - the shadows only reproduce the movement and history of the former ${ }^{94}$.

I think that to interpret the two passages we must refer to Hume on the one hand, to texts of Marx related to his Theses on Feuerbach on the other. Although with different emphases and terminology, these two passages can be read in conjunction with those of Gramsci's on the philosophy of praxis (a term that reflects a specific interpretation of materialism $)^{95}$. In the first passage the reference to the nominalist position of Hume seems clear to me. He had affirmed the existence of an irreconcilable antithesis between human reason that aspires to universal laws and the empirical observation that necessarily deals only with particulars. Moreover, the emphasis that "the causal relationship can hold only between particulars" is tantamount to a warning on the use of "abstract or general ideas" 96.

The attenuation of the rigid link between structure and superstructure (an architectural metaphor that here, however, is not used) typical of orthodox Marxism of the Second (and Third) International appears also from the retrogression of the concept of cause to 'relation of determination' (similarity, isomorphism as between body and shadow $^{97}$ ). This retrogression is consistent with the replacement of the causal with the morphological language ${ }^{98}$. The idea that ideology (here, the shadow) is also a material object had been enunciated by Lenin, and appropriated by Gramsci. By affirming that ideologies "have no history, no development", Marx wishes to emphasize, against the idealists, that the transformation of reality is not the autonomous result of thought, because the changes of the latter and of its scientific or artistic products may occur only in conjunction with the activities (praxis) of transformation.

While this aspect of Marx's position is well known, less attention has generally been paid to an implication of the crucial role of active practice highlighted in the Theses on Feuerbach, namely the implicit critique of technological determinism. In Capital, in the Chapter on 'Machinery and Modern Industry', Marx points out" that for Vico "human history differs from natural history inasmuch as we made the one but did not make the other." This forces us to rule out the application of natural scientific methods to the

\footnotetext{
${ }^{94}$ For the English translation of the two notes, see Kurz (2012).

${ }^{95}$ Other important evidence on a convergence between Sraffa's and Gramsci's interpretation of materialism in the early 1930s is provided by De Vivo (2013) in a hitherto unpublished paper presented at a Conference held in Rome at the University of Roma Tre in June 2013.

${ }^{96}$ See Hume (1969), p. 29. Hume shared Berkeley's views that general ideas are nothing but particular ideas combined with other special ideas. An echo of this nominalist position can perhaps be found in the sentence of Hodgskin, cited by Marx (1971, vol. III, p. 268) that "Capital is a sort of cabalistic word, like church or state or any other of those general terms which are invented by those who fleece the rest of mankind in order to conceal the hand that shears them".

${ }^{97}$ For the metaphor of shadows, see Marx[1847], pp.33-34-

${ }^{98}$ For Marx (see Introduction to A contribution to the critique of political economy [1857], p. 31), "The concrete is concrete because it is the summing up of many determinations, thus the unity of the manifold". For Hume's distinction between causation ("'that can be trac'd beyond our senses, and informs us of existences and objects which we don't see or feel) and resemblance ("the object of intuition"), cf. Hume (1985), p. 117 and 122.

${ }^{99}$ See Marx (1967), p. 372-73, note 3, following italics added.
} 
analysis of social reality. In addition, technology is not in fact a natural given but "reveals the active behaviour of man towards nature, the immediate process of production of his life, and with them also the immediate process of production of his vital social relations and of the ideas of the intellect that stem from them." The defects of a form of materialism "abstractly modelled on the natural sciences, which excludes the historical process — writes Marx — can already be seen in the abstract and ideological conceptions of its spokesmen [who limit themselves to the analysis] as soon as they venture outside their specialization." In conclusion, according to Marx, materialism that includes "the historical process is the only materialistic, and therefore scientific, method."

Gramsci was undoubtedly following this line of thought when he reproached Bukharin for having reduced Marxism to scientistic, mechanistic positivism, for not having dealt with the fundamental point: "how does the historical movement arise out from the structures? Yet this is the crucial point of all historical materialism." ${ }^{100}$ In other words, how to pass from the static configuration of the structure to the dynamics of the formation of a collective will oriented towards social transformation? At this point "an ethical-political element" "101 must be introduced in the philosophy of praxis, a "cathartic moment" that in various ways and forms marks the transition from economic analysis to politics. And from here the theory of intellectuals and of political party and the notion of hegemony originate.

Gramsci's reflection on this crucial point revolves around four themes that distinguish historical materialism, on the one hand from 'metaphysical' materialism, modelled on the natural sciences, on the other from idealism. The first issue concerns the two points within which the process that marks ${ }^{102}$ "the transition from the purely economic (or egoistic-passional) to the ethic-political moment, that is the processing the structure to the superstructure in the consciousness of men" oscillates [my italics]. This is the material basis of the process, inspired by an oft-quoted passage of the 1859 preface to the Contribution to a Critique of Political Economy (with reversed order with respect to Marx's formulation): that “1. Society does not set itself tasks unless the necessary and sufficient conditions (premises) for their successful completion already exist; 2. No form of society disappears until it has exhausted all its possibilities of development". The second theme concerns the relationship of historical materialism with idealism (the elimination of the contrast between subjectivism and objectivism) ${ }^{103}$ : 'the philosophy of praxis 'absorbs' the subjective conception of reality (idealism) in the theory of superstructures, it absorbs and explains it historically, that is, it 'overcomes' it, it reduces it to its moment. The theory of superstructures is the translation in terms of realistic historicism of the subjective conception of reality." The third issue concerns the distinction between "prediction" and "automatism". While the former is precluded from

\footnotetext{
${ }^{100}$ See Q. 7, $\$ 20$ p. 869 (engl. transl. vol. III, p. 171) and Q. 11,§22, p. 1422 (late 1930 - February 1931) .

${ }^{101}$ See Q. 10, \$6 p. 1244. See also Paggi (1984), pp. 459-60 .

${ }^{102}$ See Q.10, §6, p.1244.

${ }^{103}$ Ibidem.
} 
the unpredictability of social struggles ${ }^{104}$, the latter (understood as the result of the freedom of a social group to give itself "certain purposes" based on "certain principles accepted by conviction, freely)" does not, for that reason, make the behaviour of economy 'deterministic', nor does it make this conception, whose method ${ }^{105}$ is by Gramsci traced back to Ricardo, 'naturalistic'. The fourth theme concerns the replacement of mechanistic causality with dialectics (on this topic, Antonio Labriola's position has relevance). But it is not without significance that as his reflection progresses Gramsci replaces the term "dialectical causality" with the attenuated expression "dialectical impulse"

At this point I feel obliged to provide, however rashly, a few rapid indications of the meaning of the term 'dialectics' in this context. I will use the formulation proposed by Carchedi, extracted not from the writings of Hegel, but from the use that Marx made of it in his writings (I shall try to clarify below the specific meanings with which the adjective 'dialectical' appears in Gramsci's writings). According to Carchedi's interpretation, Marx's method of social research based on dialectics consists of four principles:

a) Social phenomena are always both realized and potential; i.e., reality has a double dimension, what has become realized and what is potentially existent in what has become realized. b) Social phenomena are both determinant and determined...[the latter, when realized] become the conditions of reproduction or supersession of their determinant phenomenon as well of other phenomena.

Consequently, c) social phenomena are subject to constant movement and change. d) The movement (change) of social phenomena (change) is tendential, i.e. at any given level of abstraction (given a section of reality under scrutiny) some social phenomenon is a tendency and others are the countertendencies. ${ }^{107}$

It should be emphasized that the scope of the method is society and not nature, since a crucial role is played by the voluntary and intentional action of social agents. Note, moreover, that the abstractions we are talking about are "historically determined" and not "generic" and that the order of the topics that in the Contribution to the Critique of Political Economy Marx anticipated he was willing to treat ranged from the 'simple' to the 'complex': from commodity to competition, to State, to foreign trade, to the formation of a global market. The analysis proceeds by logically separate stages, but the purpose is to reproduce the whole ${ }^{108}$ by demonstrating, through the development of genetic forms, the falsity of the view that confuses a historical process with a natural

104 For a comparative analysis of the views of Lenin, Lukàcs and Gramsci on the impossibility of forecasting, see Zanardo (1974), P.291 .

105 Gramsci refers to the method based on the analysis of the effects on the economy arising from definite hypotheses ("granted that" etc.). For the source of this formulation, see Gide and Rist (1929), p.174.

${ }^{106}$ See Cospito (2011), p. 52 quoting Q. 10, $\$ 41$, p. 1316, where Gramsci speaks of the structure "as a point of reference and of dialectical impulse for the superstructure".

${ }^{107}$ See Carchedi (2012), p. 546. While I find the synthesis reported in the text convincing, I find the use of the labour theory of value made by Carchedi in his writings less persuasive.

${ }^{108}$ Cospito (2011), p. 244, notes that the word 'organic' and related terms occur about 400 times in the Notebooks, one in every six pages of the printed edition. 
one. This seemingly naturalistic appearance provides the basis, according to Marx (and Sraffa), for 'vulgar economics' and, according to Gramsci, for 'common sense' economics ${ }^{109}$. Hence the struggle for hegemony to correct the illusion, the important role played in this struggle by the intellectuals, etc.

In moving away from deterministic or naturalistic conceptions of the economy, Gramsci developed an interest in Ricardo's 'methodological' contribution to the formulation of a "new conception of immanence, purified from all traces of transcendence and theology." In a letter dated 30 May 1932 from prison ${ }^{110}$, Gramsci, through his sister in law Tania, asks Sraffa a few questions. Can Ricardo be credited with a 'synthetic' contribution to the development of Marx's views, a contribution concerning "the intuition of the world and the way of thinking, not merely analytical, concerning a particular doctrine [the theory of value], albeit an essential one? ". In addition, using concepts such as "determined market" and "law of tendency", he wonders whether Ricardo helped to purge "the law of causality of the natural sciences... of its mechanicism" so that it could be "synthetically identified with Hegelian dialectical reasoning". In the Notebooks, the latter question is synthesized with this remark: "I think we can say that the philosophy of praxis is equal to Hegel + David Ricardo". Sraffa was, of course, unaware of the path Gramsci's had taken, and his answer was elusive and not easily explicable. He worries about the terms used by Gramsci (he wonders whether the term 'law of tendency', evidently interpreted as synonymous with a law of nature, is not associated with 'vulgar economics'), he admits his ignorance of the classics of the 'philosophy of praxis', and he reductively tends to exclude that Ricardo, who "never takes on the historical point of view", could make a philosophical/methodological contribution. Ricardo is described as "a stockbroker of mediocre culture" in whose writings "the only cultural element...is derived from the natural sciences."

In the next section, I will advance the hypothesis that Production of Commodities by Means of Commodities can be regarded as a confirmation, after many years, of Gramsci's intuition, that is the translation of his equation into the language of Hume. An important point of transition along this road is a note written by Sraffa little more than a year before Gramsci's letter.

\section{The core and historical causality}

In a note dated August 22, $1931^{111}$, Sraffa writes: "The study of the 'surplus product' is the true object of economics; the great difficulty of the matter is that this object either vanishes or remains unexplained. It is a typical problem to be handled dialectically." The problem that Sraffa raises is this: the concept of surplus is closely related to the concept of 'necessity.' You can regard it from a subjective or an objective point of

\footnotetext{
${ }^{109}$ It may recalled that in 1923 Gramsci wanted to entrust Sraffa with the responsibility for a bulletin on the problems of labour entitled "Senso Comune" ("Common Sense"). See Naldi (2000), p. 105.

${ }^{110}$ See Gramsci and Schucht (1997), pp. 1015-6.

${ }^{111}$ Sraffa papers D3/12/7, original in English.
} 
view. For example, Marshall "who tries to take a classless human standpoint, regards all men as responsible subjects and therefore all human consumption...i.e. wages, interest and rent...as part of the surplus." But "if one attempts to take an objective point of view, the very conception of a surplus melts away. For if we take this natural science point of view, we must start by assuming that for every effect there must be [a] sufficient cause, that the causes are identical with their effects, that there can be nothing in the effect which was not in the causes ${ }^{112}$ : in our case, there can be no product for which there has not been an equivalent cost, and all costs (= expenses) must be necessary." In this way, "the surplus is the object of the inquiry, but as soon as it is explained, a cause is found for it and it ceases to be a surplus." Sraffa goes on a little further with these words: "Thus it would appear that the true economic science can only study the conservative side (aspect) of things: and the revolutionary side is the object of the inadequate and contradictory economics. The revolutionary economics can only be completed by practice, which solves the contradictions and changes the facts making them adequate to their reasons." 113 After exploring this first way out of difficulty, Sraffa argues: "Another solution however lies in criticizing the above application of the principle of sufficient reason. Any given effect is entirely contained in its causes. (But these causes may contain something else besides that effect, i.e. they have other effects as well). Any given cause is entirely contained in its effects (but these effects contain more than it, i.e. they also have also other causes)... Thus there must be a leak at one end or the other: the closed system is in communication with the world." Sraffa adds a little further on: "When we have defined our 'economic field' there are still outside causes which operate in it, and its effects go beyond the boundary. This must happen in any concrete case...The surplus may be the effect of the outside causes; and the effects of the distribution of the surplus may lie outside" (italics added).

This is the only note (to my knowledge ) in which Sraffa speaks explicitly of the concept of 'core', albeit using a different term, 'economic field'. 'Core' ${ }^{114}$ is the term adopted by Garegnani to describe the theory of the determination of relative prices of goods within the theories of surplus. The peculiarity of the theories of surplus - says Garegnani $^{115}$ - is to determine the shares other than wages as the difference between a

\footnotetext{
${ }^{112}$ In the section of the Treatise entitled 'Why a cause is always necessary?' (Book I, part III, section III), Hume writes: "They are still more frivolous, who say, that every effect must have a cause, because 'tis imply'd in the very idea of effect. Every effect necessarily presupposes a cause; effect being a relative term, of which cause is the correlative. But this does not prove, that every being must be preceded by a cause; no more than it follows, because every husband must have a wife, that therefore every man must be marry'd" ( Hume 1985, pp. 129). From a similar separation between 'existence' and 'cause' (or 'origin') derive the non causal representations discussed in Ginzburg (2013).

${ }^{113}$ This plainly echoes Marx's eleventh Thesis on Feuerbach.

${ }^{114}$ In the footnote cited above of the chapter in first volume of Capital entitled 'Machinery and Modern Industry', Marx (1967), p. 372-3, note 3, refers to the "earthly core of the misty creation of religion", found through the analysis by the classical economists, while Engels, in the preface to the second volume of Capital (Marx, 1967), p. 2, calls the Theories of Surplus Value as "a detailed critical history of the pith and marrow of Political Economy, the theory of surplus value".

${ }^{115}$ See Garegnani (1981), p. 10 .
} 
given social product and a necessary consumption which is also given. The calculation of these shares, given the heterogeneity of the aggregates, requires the determination of the relative prices of goods. This is the 'core', the most abstract part of the theory, which, for this very reason, is susceptible of a general formalized treatment. Given the real wages (or the rate of profits), the quantities produced and the production techniques, the system of price equations is able to determine 'automatically' the relative prices and the rate of profits (or real wages) compatible with the competitive rule of the uniformity of rate of profits. Of course, the term 'economic field' is not to be understood as the only area of investigation of the economists. Around this theoretical core, the classical economists and Marx - I quote here from an essay by Fernando Vianello ${ }^{116}$ — "have organized the discussion of issues that can be addressed at a lower level of abstraction, such as mechanisms and forms of economic change, the circumstances that determine the level of wages and cause its change, the influence of income distribution on consumption and through it on growth". 'Lower level of abstraction' means that to study these relationships - and in particular the scramble for the division of surplus, based on strength relationships of contenders, the accumulation process and the innovations - it is essential to take historical and institutional conditions into account. In analyzing the relationships outside the 'core', deductive and inductive aspects mingle and are not clearly separable. ${ }^{117}$

This analytical procedure (which has no equivalent in the marginalist theory) has three advantages. The first is 'embeddedness': institutions, technology, policies, domestic and international relations and so on are immersed in a society where the social surplus is produced and distributed on the basis of established social relations. The second advantage is that you can take into account a plurality of causal layers that are entangled with each other without any predetermined hierarchy (hence the presence of feedback, nonlinear relationships and cumulative effects of circular causation). I propose the hypothesis that these relations can be considered as the translation of the dialectics into 'Humian' language. Through the interaction of social-historical forces operating, with respect to the 'core', to a lowest level of abstraction, the potential becomes effective, and the actual modifies the potential. The language that commonly distinguishes independent and dependent variables in a de-contextualized way leaves room here for a mutual determination in historically situated contexts of determinants and determined phenomena, as is typical of the relations of circular causation. This allows one to capture the complexity of systems in which there are strong elements of interconnection, where above all, unlike in natural systems, intentional human actions that interact at different levels and in different areas operate and produce unexpected

\footnotetext{
${ }^{116}$ See Vianello (2007), p. 72 .

117 "Algebra and arithmetic - wrote Hume (1985), p. 119 - [are].. the only sciences in which we can carry on a chain of reasoning to any degree of intricacy, and yet preserve a perfect exactness and certainty".
} 
emergent phenomena. ${ }^{118}$

The third and crucial advantage is to provide a solid analytical basis for escape from various forms of determinism: from determinism in income distribution in the first place; but also to escape from technological determinism, since technology is not a 'primary' given but an intermediate given, and is therefore explained in turn by various forces and interactions. Determinism on the quantities produced, since these are also the result of a complex interaction of forces external to the core. In addition, this method also provides an escape from two other forms of determinism: teleology and evolutionism. Marx and Engels in The Holy Family (first edition 1845, Eng. Trans. 1975, p. 167) criticized Hegel's philosophy of history: in analyzing a temporal succession of historical stages Hegel had predicted the final result of the historical process as already foreshadowed in the previous stages. In this sequence reversed, they wrote ironically, "the son engenders the mother, the spirit nature, the Christian religion paganism, the result the beginning." In other words, the ex post generates the ex ante.

One may wonder if the approach of Sraffa, who does not hesitate to speak of causes external to the core, is compatible with Hume's skeptical position regarding causation. But Hume's position was far from Pyrrhonism (as indeed his History of England ${ }^{119}$ makes clear). The argument as to whether 'habit' or 'reason' is the guide of life belongs within a cultural battle led by Hume against the 'metaphysic disease' of abstract knowledge that purports to derive the causal links deductively, thus imprisoning reality within pre-established paths.

The acceptance of a delimitation of the field between statements that are situated at different levels of abstraction is therefore connected with the need to exclude simplified causal mechanisms that, being general and universal, refer to forms of finalism: in the 'economic field' some of the effects of external causes are studied, but not the causes themselves. Sraffa's so-called 'objectivism', sometimes mistaken for a crudely scientistic attitude ${ }^{120}$, is in fact dictated by the attempt to free the analysis from any concession to finalism, which appears not only apologetic of the world as it is, but also not scientific. This perspective is legitimated by the advantages that this method can achieve: precisely because the study of the determination of quantities that depend on particular historical conditions was taken out of the 'core', ('this should be done in

\footnotetext{
118 Very close, therefore, is the analogy of this approach with some research developed around the perspective of complexity theory (see, for example, Lane 2011 and Padgett and Powell, 2012).

${ }^{119}$ See Francesconi's comment (2003, p. 74) to a passage by Hume (1985, p. 157-8). More generally, Francesconi stresses that the idea of the multiplicity of causal layers that interact in any given historical moment, the variability of the degree of influence of the past on more recent times, the different speed of history in different periods - all these belong to the conceptual vocabulary of the Scottish Enlightenment. These concepts often mingle with the two important perspectives of unintended consequences of human action and the theory of the four stages. For a critique of Hayek's interpretation of the Scottish Enlightenment, see Francesconi, ibid, pp.40-41.

${ }^{120}$ It is interesting to observe that on August 23, 1931 - that is on the day following the writing of the note previously examined - Sraffa wrote to Tania for Gramsci underlining the great ignorance of natural sciences among "Italians who have a culture". "And so - he adds - the natural sciences have been entrusted to the care of the positivists, with the well-known effects." See Sraffa (1991, p. 23, italics added). This last remark suggests a familiarity with Gramsci in the discussion of this issue.
} 
every concrete case', Sraffa points out), it is possible to take into account the multiplicity and variability of these circumstances in a much more flexible way. ${ }^{121}$

Forty days after Gramsci's death, the contents of the Notebooks were described by Togliatti in a letter to Manuilsky ${ }^{122}$, with a synthetic formulation, full of possible ambiguities but exact, as "a materialistic representation of the history of Italy." 123 The interest generated by the translations of the Notebooks indicates that the ideas contained therein, addressed to a profound critical revision of orthodox Marxism, related not only to Italy. Sraffa's writings, published and unpublished, may perhaps be interpreted as the search and eventually the proposal for a framework of economic theory consistent with that representation. In any case, these writings can be understood more fully if placed in relation with the reflections of one of its key interlocutors, who was yet totally absent from the debate among the economists.

\section{The 'historical subjectivity' of social groups and the relationship between history, economics and politics}

In the preceding pages we recalled the cultural battle fought by Gramsci on both sides of idealism or 'ethical rationalism', on the one hand, and 'dogmatic' or 'orthodox' Marxism, often called 'dialectical materialism', on the other. As from the years 1924$26^{124}$, Gramsci conducts this battle basing himself on indications from Antonio Labriola and Lenin, and in a more systematic way in the Notebooks, developing the position at which Marx arrived after his detachment from the materialism of Feuerbach.

If we are to understand the meaning of the crucial questions addressed to Sraffa in the aforementioned letter of 1932 (to which I will return shortly), we must refer to Gramsci's process of elaboration along this line of research. But this is necessary also for two other reasons: to avoid misunderstanding Sraffa's book of 1960 on the theme of subjectivity/objectivity if one accepts the idea proposed here that this work could also be seen as a belated response, in the language of Hume, to those questions; and to fully understand the scope of Sraffa's turnaround, from the pre-lectures written in the summer-fall of 1927 to the notes in August 1931.

\footnotetext{
${ }^{121}$ On this point see this passage by Gramsci (Q.7,§24, pp. 871-2, Engl. transl. vol. III, p.173) : “An analysis [of the historical and political works of Marx] allows one to get a better grasp of Marx's historical method, integrating, illuminating and interpreting the theoretical affirmations scattered throughout his works. One can see how many real cautions Marx introduces in his concrete research, cautions that could have no place in the general works." It is interesting that the only projected edition of Marx's writings in which Sraffa was directly involved is the collection of the correspondence of Marx and Engels to the New York Daily Tribune for the Italian publisher Feltrinelli, a project interrupted in November 1962 (cf. Daniele 2000, pp. 98-103).

${ }^{122}$ The document, in German, was found by Silvio Pons in the Archives of the Russian social and political history (RGASP1, dossier 1945, inventory 12, folder 152).

${ }_{123}$ On May 20, Togliatti wrote to Sraffa "I have no idea even approximate [of the contents of the Notebooks]. What is it?" See Spriano (1977), p. 165. This suggests that the synthetic description of the contents of the Notebooks provided by Togliatti goes back to Sraffa.

${ }^{124}$ See Paggi (1984), p. 444 and 456.
} 
In the aforementioned letter ${ }^{125}$ to Tania in May 1932, Gramsci aroused Sraffa's perplexity by formulating the hypothesis that the two concepts attributed to Ricardo and called "essential for economic science", "determined market" and "law of tendency", had helped to direct Marx and Engels "to overcome the Hegelian philosophy and build their new historicism, purified of any speculative logic". In particular, Gramsci asked Sraffa if we could say that these concepts had been the starting point for the construction of "a realistic, immediately historical 'immanence', in which the law of causality in the natural sciences has been purified from its mechanicism and was synthetically identified with the Hegelian dialectical reasoning". These questions arose from some reflections of Gramsci's ${ }^{126}$ on the implications of the Sixth Thesis on Feuerbach. In the passage of Prison Notebooks entitled Materialism and Historical Materialism, Gramsci asks whether it would make sense to "create a science of man (a philosophy) which starts from an initially 'unitary' concept, an abstraction in which everything human may be contained". A search of this type raises the question "what is man?". But the acceptance as a starting point (and not as a point of arrival) of the quest for concepts such as 'human nature' or 'man in general' - Gramsci writes - reveals a flawed approach that indicates the presence of a " "theological" or 'metaphysical' residual." In the Sixth Thesis on Feuerbach, Marx had written ${ }^{127}$ : "the human essence is not abstraction inherent in each single individual. In its reality is the ensemble of the social relations." In this regard, Gramsci had noted ${ }^{128}$ :

That 'human nature' is the 'ensemble of social relations' is the most satisfying answer, because it includes the idea of becoming - man becomes, he changes continuously with the changing of social relations; and because it denies 'man in general': Indeed, social relations are expressed by diverse groups of men that presuppose one another, and their unity is dialectical, not formal. Man is aristocratic insofar as man is a serf... One could also say that the nature of man is "history" ... if history is taken to mean, precisely, 'becoming' in a concordia discors that does not have unity for its point of departures but it contains in itself the reasons for a possible unity.

Gramsci identifies the main innovation of Marxism in the discovery of the concept of 'social relations of production' that change as the position of social classes to one another alters. Embedding the roots of human historicity in social relations is the only way to escape the metaphysical vice of using "dogmatically "unitary' concepts" such as 'man in general', or 'human nature', that are ideological concepts, ultimately apologetic with respect to the existing social order. The history of man is the history of the division of society into social classes. "The real subject of history, then, are social groups that confront each other and define their respective physiognomies through this antagonistic comparison... The true humanism, the absolute humanism, is reached only by relinquishing any philosophy of man and thus any form of historicism that does not

\footnotetext{
${ }^{125}$ See Gramsci and Schucht (1997), p. 1015-6.

${ }^{126}$ In the following I have used the analysis conducted by Paggi (1984), p. 436-442.

${ }^{127}$ See Marx [1845], Eng. trans. in the Appendix to Engels (1969), p. 84.

${ }^{128}$ See Gramsci, Q. 7, § 35, p. 885, italics added (engl. transl vol. III, p.186).
} 
conduce to the dual identification of the concept of 'history' with that of social relations of production and of 'becoming' with the antagonistic development of these relations." 129

The notion of 'determined market' and that of 'law of tendency' purified of mechanicism correspond to the two elements of this dual identification. The 'determined market' refers to an abstraction historically determined ${ }^{130}$, that is the concept of social relations of production. The 'law of tendency' purified of mechanicism refers instead to the development of antagonistic relations themselves, which arise from the inverse relationship between wages and the rate of profits (and, more generally, from the theory of value and distribution). How does this 'purification' occur? Here a crucial role is played by 'dialectics', a term that, in fact, identifies the problem of causality in the analysis of concrete historical and political processes ${ }^{131}$. If historical investigation is conducted with the methods of the natural sciences, or the superstructure is derived mechanically from the structure, there is no escape from evolutionary determinism and fatalism. In this case, Gramsci writes ${ }^{132}$ :

The law of causality, the search for regularity, normality, uniformity are replaced by historical dialectics. But how from this way of thinking may the 'overthrow of praxis' be inferred? The effect, mechanically, can never exceed the cause or system of causes, so there can be no other development than flat, vulgar evolutionism.

As noted by Bobbio ${ }^{133}$, the use of the term 'dialectics' in the writings of Gramsci has three basic meanings: 'reciprocal action' (if the word is associated with 'relationship', 'nexus', 'unit'); 'process', through thesis, antithesis and synthesis (when it is combined with 'movement', 'process', 'development'); and 'transformation of quantity into quality and vice versa'. In each of these meanings, the logic of (multiple) connections and of transformation replaces the logic of linear causality. The central, propulsive role attributed in the 'dialectical process' to conflict (the antithesis, the antagonism of fighting parties) precludes the use of the language of dialectics for the mere purpose of

\footnotetext{
${ }^{129}$ See Paggi (1984), p. 437.

${ }^{130}$ Gramsci writes, in Q. 10 §32, pp. 1276-7: “'For 'pure' economics, a 'determined market' is an arbitrary abstraction that assumes a purely conventional value for the purposes of a pedantic and scholastic analysis. For critical economics it will instead include the whole of concrete economic activities of a specific social form, taken in their rules of uniformity, that is 'abstract', but where the abstraction will not cease to be historically determined ". For a possible indirect reference to an article by P. Iannaccone, cf. Ginzburg (2000), p. 137, note 86 .

${ }^{131}$ It may seem surprising today that, in the political battle and in publications aimed at militants, first Lenin, later Gramsci, were using the writings of Hegel on dialectics to claim, against positions considered eclectic and unilateral (syndicalism, 'metaphysical materialism'), the superiority of multilateral conceptions able to approximate the reconstruction of the totality. For an important source of reflection for Gramsci, see the writings of Lenin 'On the question of dialectics' - published in German in 1925, now in Lenin (1976, pp. 357-361) - and the remarkable 'educational' article by Lenin on dialectics (Lenin 1965) to which Paggi (1984, pp. 455-6), has drawn attention, published by Gramsci in L'Unità in January 1926. Lenin's arguments and examples are strikingly similar to those proposed recently by a well-known scholar of complexity theory, Stuart A. Kauffmann (2013, p. 9). It is ironic that both Lenin and Gramsci utilized dialectics to criticize dialectical materialism and Marxism-Leninism.

${ }^{132}$ See Q. 10, § 14, p. 1403.

${ }^{133}$ See Bobbio (1990), p.28.
} 
increasing the number of variables considered so that this element could be considered the only criticism raised against more simplistic interpretations: "dialectics is the tool by which the consideration of the multiplicity of factors is traced back and subjected to the specific mode of being of the fundamental contending forces... and indicates the way in which, through the exclusion of other objectively possible alternatives, a certain outcome is reached." 134

Three main consequences can be derived from this, and they can be used to explore the hypothesis advanced earlier, namely the possibility to use Gramsci to 'read' Sraffa's 1960 book. The first concerns the central role of historical subjectivity of social groups. In Sraffa's scheme, this role is evident both in the construction of the inverse relationship between wages and the rate of profit, and in all external relations to the 'core' involving, in addition to distribution, production techniques ${ }^{135}$ and quantities produced. Therefore, it is reductivist and possibly misleading (as influenced by Marshall's interpretation of the two blades, cost and demand, which independently determine the price) to describe Sraffa's position without qualifications and only as 'objectivist': the usual opposition objectivism/subjectivism can be used only in the context of admitting and distinguishing different definitions of 'subjectivity'. For instance, there are reasonable grounds to rule out that the subject, inevitably social, is adequately represented in the atomistic agent of marginalist theory.

The second consequence concerns Gramsci's refusal to consider the 'philosophy of praxis' as a general theory, a pre-conceived form to be filled with different cases, rather than as "a method of knowledge by which to arrive at a concrete and realistic depiction of the antagonistic unity of society." 136 In the case of Sraffa, a similar refusal is expressed by the concept of 'core', which separates the narrow zone of the automatism from the interdependence of the multiple and variable relations external to the 'core', 'situated' in well defined historical time and space.

The third consequence concerns the relationship between history, economics and politics. The notion of social relations of production brings philosophy back to history, and historical subjectivity of social groups back to politics. In this perspective, "the general concepts of history, politics and economics are woven together in an organic unity." 137

If one accepts the hypothesis that has been proposed in the previous pages, it is possible to measure the extent of the change in Sraffa's position after his theoretical 'turning point' as compared to the one present at the beginning of the summer of 1927 , when he was starting to prepare the pre- lectures. Accepting a position that could be called 'Engelsian', Sraffa at the time relied on the "general scheme of the development of science" for addressing the task of transforming economic science into a technique,

\footnotetext{
${ }^{134}$ See Paggi (1984), p. 452. In a letter to Tania of 25 March 1929, Gramsci defines dialectis as "the form of historically concrete thought". See Gramsci and Schucht, (1997, p.334.

${ }^{135}$ Already in the Ordine Nuovo - cf. Paggi (1984, p. 442) - Gramsci stressed "the 'politicization' of the world of production".

${ }^{136}$ See Paggi (1984), p. 454 .

${ }^{137}$ See Q.11 §33, p. 1448 and Paggi (1984, p. 454).
} 
purged of its philosophical elements. In the elaboration started in the fall of 1927 that would achieve a complete formulation in 1960, the representation of the capitalist economic system is consistent with the idea of a theory of history "where it is impossible to separate politics from economics". 138 The question whether and to what extent Sraffa considered that the October Revolution had provided a justification for a return, in the Soviet Union, to an Engelsian position remains open for further research. If so, it would be difficult to follow Sraffa along this road.

\section{Sraffa contended}

Sraffa's book published in 1960 contains both the 'prelude' to a critique of economic (marginalist) theory, as indicated by the subtitle, and the proposal for a return to the approach of classical political economy and Marx. The possibility to perform both tasks is given by the fact that the same equations that describe the equality of prices to the sum of the costs and unit profits can be interpreted in an entirely different manner according to the theory of distribution adopted. One could say that the setting of the book is consistent with the following suggestion of Gramsci's ${ }^{139}$ : "If we want to defend the critical conception of the economy, we must systematically insist that orthodox economics treats the same problems in another language, demonstrating this identity of the problems dealt with and showing that the critical solution is superior to the other: in short, texts must always be 'bilingual', the authentic text and its 'vulgar' or free market translation, next to one another".

As far as the critique of marginalist theory is concerned, interpretations of the meaning of Sraffa's contribution are less controversial than those relating to his constructive or reconstructive contribution. A recent special issue of Cambridge Journal of Economics $(36,2012)$ was mainly devoted to this second aspect: it hosted the papers presented at a conference organized in 2010 in Cambridge to recall the figure of Sraffa almost a decade after the opening of the archive holding his papers and fifty years after the publication of Production of Commodities by Means of Commodities. I must note with regret that the interpretation put forward by Garegnani in 1981, based on the separation between internal and external relations with respect to the 'core' and thus on the necessity of a diversity of methods needed to analyze them, has not been taken up by the participants at the conference dedicated to these issues. The term 'core' has simply disappeared, as if an "abysmal gulf of incomprehension" had suddenly opened between us and Marx, Sraffa and Gramsci (in this re-opening of the abyss the external social conditions undoubtedly have relevance for research activity). The perplexity is all the greater as the possibility to access Sraffa's papers gives support to Garegnani's interpretation - as we have sought to argue here, albeit with different emphases and arguments. The interpretations provided seem to me to be driven by the (obviously legitimate) research themes of the interpreters and not by those of the author that they seek to interpret. (In the preceding pages we have tried to argue instead that Sraffa's

\footnotetext{
${ }^{138}$ See Q.11, $\$ 33$ p. 1448.

${ }^{139}$ See Q.10, §20, pp. 1258-9.
} 
reading of the texts of Marx in the Theses on Feuerbach has important intersections with that of Gramsci). For example, Pasinetti has said" ${ }^{140}$ that "In Production of Commodities by Means of Commodities...[Sraffa]...does not rely on any institutional set-up, he does not make reference to any historical context, he does not mention any kind of 'economic agent'. He carefully avoids making any assumptions on human behaviour, on market structure, on competition, on returns to scale. He even avoids taking any explicit stand on the distribution of income, for which he does not commit himself to the way in which the rate of profit (or alternatively the wage rate) is determined. The rate of profits is simply considered as an independently determined variable". Conversely, Kurz flattened Sraffa (and Marx) on a reductive conception of materialism, the study of material objects, a (rough) abstractly scientistic 'objectivism'141. Again, a choice is proposed between two alternatives, both monistic, between Pasinetti's idealism of the 'generic abstractions' or Bukharin's 'metaphysical' materialism. The efforts made by Gramsci's and Sraffa's research to overcome these alternatives were, apparently, useless.

\section{References}

Andrews D.R. (1999). Continuity and Change in Keynes's thought: the importance of Hume, in The European Journal of the History of Economic Thought, 6:1, Spring, 121.

Andronico M. (1998). Antropologia e metodo morfologico. Studio su Wittgenstein, Napoli: La Città del Sole.

Auletta F. (2008). Piero Sraffa e Antonio Gramsci: 1'“Ordine nuovo" e le lotte operaie in Inghilterra e in America (1921), in F. Giasi (ed.), Gramsci nel suo tempo. Roma: Carocci.

Bacon F. (1605 [2000]). The Advancement of Learning, M. Kiernan (ed.), The Oxford Francis Bacon, vol. 4, Oxford: Clarendon Press.

Bacon F. (2004). Novum Organum and associated texts, G. Rees and M. Wakely (eds), The Oxford Francis Bacon, vol. 11, Oxford: Clarendon Press.

Bellino E. and Wirkierman A.L. (2011). Surplus Approach to Value and Distribution and Structural Economic Dynamics. Interpretation and Uses of Sraffa's Analysis, in N. Salvadori and C. Gehrke (eds), Keynes, Sraffa, and the Criticism of Neoclassical Theory - Essays in Honour of Heinz D. Kurz, Abingdon and New York: Routledge.

Bellofiore R. (2001). Monetary Analyses in Sraffa's Writings: A Comment, in T. Cozzi and R. Marchionatti (eds), Piero Sraffa's Political Economy: a Centenary Estimate, London and New York: Routledge.

Bobbio N. (1990). Gramsci e la dialettica, in Saggi su Gramsci, Milano: Feltrinelli.

Bucharin N. (1977). Teoria del materialismo storico. Manuale popolare di sociologia marxista, introduction by V. Gerratana, Firenze: Nuova Italia.

\footnotetext{
${ }^{140}$ See Pasinetti (2012, p. 1312). More generally, on the role of "historical factors in the "spheres of distribution, accumulation and technical change"" as an element that differentiates the "surplus approach to value and distribution' proposed by Garegnani from the 'structural economic dynamics' by Pasinetti, see Bellino and Winkierman (2011, p.164).

${ }^{141}$ See also Kurz and Salvadori (2005).
} 
Boothman D. (2004). Traduzione e traducibilità, in F. Frosini and G. Liguori (eds), Le parole di Gramsci. Per un lessico dei Quaderni del carcere, Roma: Carocci.

Carchedi G. (2012). Mathematics and Dialectics: a Reply, in Science \& Society, 76:4, October, 546-549.

Clark J.B. (1899 [1965]). The Distribution of Wealth: a theory of wages, interest and profits, New York: Kelley.

Colorni E. (2009). La malattia della metafisica, Torino: Einaudi.

Cospito G. (2011). Il ritmo del pensiero. Per una lettura diacronica dei 'Quaderni del carcere' di Gramsci, Napoli: Bibliopolis.

Cozzi T. and Marchionatti R. (eds) (2001). Piero Sraffa's Political Economy: a Centenary Estimate, London and New York: Routledge.

Cunningham W. (1892). A Plea for Pure Theory, Economic Review, 11, January, 25-41.

Daniele C. (2000). Le fonti e gli archivi: tracce di un percorso italiano di Piero Sraffa nel secondo dopoguerra, in M. Pivetti (ed.), Piero Sraffa: contributi per una biografia intellettuale, Roma: Carocci.

De Vivo G. (2003). Sraffa's Path to Production of Commodities by Means of Commodities. An Interpretation, in Contributions to Political Economy, 22, 1-25.

Di Meo A. (2008). L'oggettività del reale: riflessioni gramsciane su scienza e neotomismo in M. Paladini Musitelli (ed.), Gramsci e la scienza, Trieste: Istituto Gramsci del Friuli Venezia Giulia.

Dobb M.H. (1937). Political Economy and Capitalism, London: Routledge.

Engels F. (1888 [1969]). Ludwig Feuerbach e il punto d'approdo della filosofia classica tedesca, Roma: Editori Riuniti.

Francesconi D. (2003). L'età della storia. Linguaggi storiografici dell'illuminismo scozzese, Bologna: Il Mulino.

Frosini F. (2004). Filosofia della praxis, in F. Frosini and G. Liguori (eds), Le parole di Gramsci. Per un lessico dei Quaderni del carcere, Roma: Carocci.

Frosini F. (2010). La religione dell'uomo moderno. Politica e verità nei 'Quaderni del carcere' di Antonio Gramsci, Roma: Carocci editore.

Frosini F. and Liguori G. (eds) (2004). Le parole di Gramsci. Per un lessico dei 'Quaderni del carcere', Roma: Carocci.

Garegnani P. (1981). Marx e gli economisti classici, Torino: Einaudi.

Garegnani P. (2004). Di una svolta nella posizione teorica e nella interpretazione dei classici in Sraffa nei tardi anni '20, in Piero Sraffa, Atti dei Convegni Lincei, Roma: Accademia Nazionale dei Lincei.

Garegnani P. (2005). On a turning point in Sraffa's theoretical and interpretative position in the late 1920s, in European Journal of the History of Economic Thought, 12:3, September, 453-492.

Garin E. (1983). Tra due secoli. Socialismo e filosofia in Italia dopo l'Unità, Bari: De Donato.

Gehrke C. and Kurz H.D. (2006). Sraffa on von Bortkiewicz: reconstructing the Classical Theory of Value and Distribution, History of Political Economy, 38, 91149.

Giasi F.(ed.) (2008). Gramsci nel suo tempo, Roma: Carocci.

Gide C. and Rist C. (1929). Histoire des doctrines économiques depuis les physiocrates jusqu'à nos jours, Paris: Sirey.

Gilibert G. (2003). Equations Unveiled. Sraffa's Price Equations in the making, in Contributions to Political Economy, 22, 27-40. 
Ginzburg A. (2000). Sraffa e l'analisi sociale: alcune note metodologiche, in M. Pivetti (ed.), Piero Sraffa: contributi per una bibliografia intellettuale, Roma: Carocci.

Ginzburg A. (2013). Sraffa, Sen and non-causal representations in social analysis in E.S. Levrero, A. Palumbo and A. Stirati (eds), Sraffa and the Reconstruction of Economic Theory, vol. 3: Sraffa's Legacy. Interpretations and Historical Perspectives, London: Palgrave Macmillan.

Giolitti A. (1992). Lettere a Marta, Bologna: Il Mulino.

Gramsci A. and Schucht T. (1997). Lettere 1926-1935, Torino: Einaudi.

Gramsci A. (1975). Quaderni del carcere, critical edition by V. Gerratana, Torino: Einaudi.

Gramsci A. (1978). La costruzione del Partito Comunista, 1923-1926, Torino: Einaudi.

Gramsci A. (1984). Il nostro Marx. 1818-19, Torino: Einaudi.

Gramsci A. (1992-2007). Prison Notebooks, vols 1-3, Buttigieg J.A. (ed.), New York: Columbia University Press.

Henning B.G., Scarfe A. (eds) (2013). Beyond Mechanism: Putting Life back into Biology, Lanham: Lexington Books.

Hertz H. (1894 [English translation 1956]. The Principles of Mechanics presented in a new form, New York: Dover Publications.

Hesse M. (1998). Francis Bacon's Philosophy of Science, in B. Vickers (ed.), Essential Articles for the study of Francis Bacon, Hamden, Connecticut: Archdon Books.

Hume D. (1739-40 [1985]). A Treatise of Human Nature, London: Penguin Books.

Hume D. (1740 [1938]). An Abstract of a Treatise on Human Nature, reprinted with an Introduction by J.M. Keynes and P. Sraffa, Cambridge: Cambridge University Press.

Kauffman S.A. (2013). Preface to B.G. Henning, A. Scarfe (eds), Beyond Mechanism: Putting Life back into Biology, Lanham: Lexington Books..

Kurz H. and Salvadori N. (2005). Representing the Production and Circulation of Commodities in Material Terms: on Sraffa's Objectivism, in Review of Political Economy, 17:3, July, 69-97.

Kurz H.D. (2012). Don't treat too ill my Piero! Interpreting Sraffa's Papers, Cambridge Journal of Economics, 36, 1535-1569.

Labriola Antonio (1977). Saggi sul materialismo storico, Roma: Editori Riuniti.

Labriola Arturo (1897). Le dottrine economiche di F. Quesnay, Napoli: E. Croce.

Labriola Arturo (1921). Il valore della Scienza Economica. Introduzione a una critica dell'Economia Politica, Napoli: Morano.

Lane D.A. (2011). Complexity and Innovation Dynamics, in C. Antonelli (ed.), Handbook on the Economic Complexity of Technological Change, Cheltenham, UK and Northampton, MA, USA: Edward Elgar.

Lecaldano E. (1991). Hume e la nascita dell'etica contemporanea, Bari, Laterza.

Lenin V.I. (1921 [1965]). Once again on the Trade Unions, in Collected Works, vol. 32, Moscow: Progress Publishers.

Lenin V.I. (1915 [1976]). On the Question of Dialectics, in 'Philosophical Notebooks', Collected Works, vol. 38, Moscow: Progress Publishers.

Liguori G. (1976, 2012). Gramsci conteso, Roma: Editori Riuniti.

Lippi M. (1976 [1979]). Value and Naturalism in Marx, London: NLB.

Luciani V. (1947). Bacon and Machiavelli, Italica, 24, 26-40.

Ives P. (2004). Gramsci's Politics of Language. Engaging the Bakhtin Circle \& the Frankfurt School, Toronto: University of Toronto Press. 
Ives P. and Lacorte R. (eds) (2010). Gramsci, Language and Translation, Plymouth: Lexington Books.

Izzo F. (2009). Democrazia e cosmopolitismo in Gramsci, Roma: Carocci.

Marcuzzo M.C. (2004). Sraffa all'Università di Cambridge, in Piero Sraffa, Atti dei Convegni Lincei, Roma: Accademia Nazionale dei Lincei.

Marx K. (1857 [1976]). Introduction to A Contribution to the Critique of Political Economy, Peking: Foreign Language Press;

https://archive.org/details/PrefaceAndIntroductionToAContributionToTheCritiqueOfPolit icalEconomy,

Marx K. (1971), Theories of Surplus Value, vol. 3, Moscow: Progress Publishers.

Marx K. (1845 [1969]). Theses on Feuerbach, http://www.marxists.org/archive/marx/ works/1845/theses/theses.htm

Marx K. [1847]. Poverty of Philosophy, https://www.marxists.org/archive/marx/works/ download/pdf/Poverty-Philosophy.pdf

Marx K. [1857]. Introduction to A contribution to the critique of political economy, http://archive.org/stream/PrefaceAndIntroductionToAContributionToTheCritiqueOf PoliticalEconomy/preface_djvu.txt

Marx K. (1967). Capital. Critique of political economy, vols 1 and 2, New York: International Publishers.

Marx K, (1875 [1966]). Critique of The Gotha Programme, New York: International Publishers.

Marx K. and Engels F. (1846 [1978]). The German Ideology, Moscow: Progress Publishers.

Marzani C. (1957). The Open Marxism of Antonio Gramsci, New York: Cameron Associates.

Naldi N. (2000). The friendship between Piero Sraffa and Antonio Gramsci in the years 1919-1927, in European Journal of the History of Economic Thought, 7:1, Spring, 79-114.

Naldi N. (2008). Piero Sraffa "politico" nel 1924. Una lettura, in F. Giasi (ed.), Gramsci nel suo tempo, Roma: Carocci.

Padgett J. F. and Powell W. W.(2012). The Emergence of Organizations and Markets, Princeton: Princeton University Press.

Paggi L. (1974). La teoria generale del marxismo in Gramsci, in Storia del marxismo contemporaneo. Annali Feltrinelli 1973, 15, 1318-1370, republished with the title Da Lenin a Marx in L. Paggi (1984), Le strategie del potere in Gramsci. Tra fascismo e socialismo in un solo paese. 1923-1926, Roma: Editori Riuniti, 427-498.

Paggi L. (1984). Le strategie del potere in Gramsci. Tra fascismo e socialismo in un solo paese, 1923-1926, Roma: Editori Riuniti.

Pasinetti L.L. (2012). Piero Sraffa and the Future of Economics, Cambridge Journal of Economics, 36, 1303-1314.

Perri S. (2010). From the «Loaf of Bread» to «Commodity Fetishism»: a 'New Interpretation' of the Marx-Sraffa Connection, in History of Economic Ideas, 18:1, 33-59.

Pivetti M. (ed.) (2000). Piero Sraffa: contributi per una bibliografia intellettuale, Roma: Carocci.

Poincaré H. (1902). La Science et l'Hypothèse, Paris: Flammarion. 
Potier J.P. (2000). Qualche nota sulla biografia di Sraffa alla luce delle sue carte, in M. Pivetti (ed.), Piero Sraffa: contributi per una bibliografia intellettuale, Roma: Carocci.

Ravagnani F. (2000). Su una frequente caratterizzazione della teoria classica del valore, in M. Pivetti (ed.), Piero Sraffa: contributi per una bibliografia intellettuale, Roma: Carocci.

Ravagnani F. (2001). Notes on a Mischaracterization of the Classical Theory of Value, Review of Political Economy, vol. 13:3, 355-363.

Roncaglia A. (1985). Petty: the origins of political economy, M.E. Sharpe, New York (it. Edition, 1977).

Rosselli A. and Trabucchi P. (2010). Sraffa, il metodo "marginale" e il "cambiamento", in G. Bonifati and A. Simonazzi (eds), Il ritorno dell'economia politica. Saggi in ricordo di Fernando Vianello, Roma: Donzelli.

Rossi A. and Vacca G. (2007). Gramsci fra Mussolini e Stalin, Roma: Fazi editore.

Rossi-Landi F. (1968). Il linguaggio come lavoro e come mercato, Milano: Bompiani.

Salvadori N. and Gehrke C. (eds) (2011). Keynes, Sraffa and the Critique of Neoclassical Theory, London: Routledge.

Scribano E. (2008). Hume and Spinoza on the relation of Cause and Effect, in D. Garber and S. Nadler (eds), Oxford Studies in Early Modern Philosophy, 4, 227-243.

Spencer M.G. (2003). Another "Curious Legend" about Hume's An Abstract of a Treatise on Human Nature, in Hume Studies, 29:1, April, 89-98.

Spriano P. (1967). Gli ultimi anni di Gramsci in un colloquio con Piero Sraffa, in 'Gramsci trent'anni dopo', Rinascita- Il Contemporaneo, 14 aprile.

Spriano P. (1977). Gramsci in carcere e il partito, Roma: Edizioni 1'Unità.

Sraffa P. (1926). The Laws of Returns Under Competitive Conditions, in Economic Journal, 36, 535-550.

Sraffa P. (1991). Lettere a Tania per Gramsci, Roma: Editori Riuniti.

Steve S. (2004). Testimonianza di un amico, in Piero Sraffa, Atti dei Convegni Lincei, Roma: Accademia Nazionale dei Lincei.

Vacca G. (2000). Sraffa come fonte di notizie per la biografia di Gramsci, in M. Pivetti (ed.), Piero Sraffa: contributi per una bibliografia intellettuale, Roma: Carocci.

Vacca G. (2012). Vita e pensieri di Antonio Gramsci. 1926-1937,Torino: Einaudi.

Valiani L. (1983). Dalla tesi di laurea all'impegno nell'antifascismo, Corriere della sera, 6 settembre.

Vianello F. (2007). Paolo Sylos Labini economista classico, in Economia \& Lavoro, 3 , 71-83.

Voltolini A. (2006). Introduction to L. Wittgenstein, Causa ed Effetto seguìto da Lezioni sulla libertà del volere, Torino: Einaudi.

Whitehead A. N. (1925). Science and the Modern World, New York: Mac Millan.

Wittgenstein L.(2006). Causa ed Effetto seguìto da Lezioni sulla libertà del volere, (ed. by A. Voltolini), Torino: Einaudi [Italian translation of two essays included in Wittgenstein L. (1993)].

Wittgenstein L.(1993). Philosophical Occasions 1912-1951, Indianapolis-Cambridge: Hackett.

Zanardo A. (1974). Filosofia e socialismo, Roma: Editori Riuniti. 